\title{
Cerámica vidriada de época emiral en Córdoba
}

\author{
Glazed ceramic from Emirate phase in Cordova (Spain)
}

\author{
Elena Salinas *
}

\begin{abstract}
RESUMEN
A continuación se presenta una aproximación a la cerámica vidriada cordobesa de época emiral. En primer lugar, se realiza un breve recorrido por los escasos hallazgos exhumados y publicados en Córdoba (España). Seguidamente se estudia un conjunto de especial interés por tratarse de un contexto cerrado, datado entre finales del siglo IX y principios del X. La importancia del hallazgo radica en la calidad de las piezas y la variedad en sus formas y decoraciones. Algunas de las piezas presentan similitudes con cerámicas andalusíes, como Pechina (Almería), mientras otras encuentran paralelos con cerámicas orientales.
\end{abstract}

Palabras clave: al-Andalus, Cerámica vidriada, periodo emiral, Córdoba.

\section{INTRODUCCIÓN}

Durante mucho tiempo se ha pensado, por falta de hallazgos arqueológicos y por desconocimiento, que en Córdoba no había cerámica vidriada emiral. Esto chocaba con otros conjuntos cerámicos de distintos lugares de al-Andalus, donde sí se habían documentado piezas vidriadas fechadas en época emiral con clara influencia oriental.

Como hemos dicho esta ausencia cordobesa se ha debido fundamentalmente a dos factores. Uno, al desconocimiento: gran parte de

\begin{abstract}
This paper is a first approximation to the glazed ceramic from Cordova (Spain) from Emirate phase. Firstly, there is a summary of a few findings exhumed and published in Cordova. Then, a study of a very interesting ceramic assemblage is presented due to it being a closed context, dated to the late 9th or early I Oth centuries. The importance of this discovery lies in the quality of the pieces and the variety in their forms and decorations. Some of these pieces have similarities with other ceramics from al-Andalus, such as Pechina (Almería), while others have parallels with Oriental ceramics.
\end{abstract}

Key words: al-Andalus, glazed pottery, Emirate phase, Cordova.

las excavaciones previas al boom urbanístico, es decir anteriores al año 2000, se habían realizado en el casco histórico de la ciudad. En estas excavaciones la estratigrafía es muy compleja, pues existe una superposición de la ciudad desde época romana republicana a la actualidad, sin interrupción, y no se identificaban correctamente los contextos tardoemirales. Durante mucho tiempo, la ausencia de vidriado en los contextos era signo inequívoco de su datación emiral, mientras que la presencia de vidriado y verde y morado o verde y manganeso servía para datar el conjunto como califal, o a veces como tardoislámico o almohade. 
En segundo lugar, el crecimiento urbanístico que ha experimentado la ciudad en los últimos años ha multiplicado las actuaciones en el subsuelo y como consecuencia del aumento de actividades arqueológicas ha crecido también el volumen de material cerámico procedente de las mismas.

Una vez analizados varios conjuntos se ha detectado la presencia de piezas vidriadas procedentes de contextos emirales, en un arco cronológico que comprende desde la segunda mitad del siglo IX hasta el primer tercio del siglo $X$. Comprobándose por tanto, y al contrario de lo que se creía, que el vidriado emiral es un elemento constante en el registro arqueológico y no un hecho aislado como se ha pensado durante mucho tiempo. A pesar de que el único hallazgo publicado y conocido hasta hace poco era el jarrito vidriado en verde, que presenta triángulos aplicados y procede de Cercadilla (FUERTES e HIDALGO, 2003, 538, figs. 23-24) (Fig. I:I)

Si rastreamos en las publicaciones encontramos otra pieza vidriada procedente de la plaza Mármol de Bañuelos situada en el interior de la Medina e identificada erróneamente como almohade. Este jarrito conserva unas pequeñas patas en la base e incisiones diagonales que alternan con impresiones de media caña y forman una especie de escamas u ovas (SERRANO y CASTILLO, 1992, 88-97) (Fig. I :2). Estos motivos se repiten en el Tolmo de Minateda (Hellín, Albacete) (GUTIÉRREZ, GAMO y AMORÓs, 2003, 153- I56, fig. 10.9, II, I3- |4), Baŷỹāna, Pechina (Almería) (CASTILLO y MARTíNEZ, 1993, 86-100, láms. VI, 3, 7-8, VII, I y IX, 4, 9) y Calatrava la Vieja (RETUERCE et alii, 2009, lám. 1:7).

En una intervención de la avenida de las Ollerías (Fig. I:3) hallamos, en los niveles anteriores a la formación de la zona alfarera califal y almohade, una pieza inédita vidriada en verde con un pequeño apéndice o pata en la base y nervios verticales aplicados en la superficie exterior

Más espectacular es el lote inédito localizado en una excavación realizada en la calle $M^{a}$ Auxiliadora (Fig. 1:4). Corresponde a una vaguada que comienza a rellenarse en un momento avanzado del emirato y que continúa colmatándose hasta época bajomedieval cristiana. En los niveles inferiores se recuperaron varias piezas vidriadas, entre las que destacan un cuenco vidriado en verde con aplicaciones de nervios o bastoncillos que forman rombos y presentan punzamientos en el interior (Lám. I:I), un jarrito vidriado en verde con pequeños apéndices 0 patas en la base y un esquema ornamental que alterna incisiones verticales con una especie de escamas $u$ ovas realizadas con cuño (Lám. I:2), similar al localizado en la plaza Mármol de Bañuelos (SERRANO y CASTILLO, 1992, 88-97). También se documentó otro fragmento vidriado en tonos achocolatados con una pequeña pata en la base y en cuyas paredes se desarrollan varias molduras horizontales con incisiones (Lám. I:3), similar a otra pieza identificada como parte de un jarro en Cartagena (MURCIA y GUILLERMO, 2003, 209-210, fig. 19, 136), otro en Málaga (ACIÉN et alii, 2003, 420, fig. 7, n⿳ 65), un fragmento en Calatrava la Vieja (RETUERCE et alii, 2009, lám. I: I, pieza I) y otro en Gormaz, Soria (RETUERCE, 1998, 409, n 479); encontramos una pieza similar, con moldura y tres patas, pero con engobe y restos de pintura en Cercadilla (FUERTES y GONZÁLEZ, 1994, 285286, fig. 8, $\left.n^{\circ} 4\right) ; y$ por supuesto, se recuperaron fragmentos con vidriados moteados en verde o melado.

En la excavación del Patio de Mujeres del Alcázar de los Reyes Cristianos (Fig. 1:5) se identificó un fragmento, sin publicar, que pertenece a un jarro vidriado en verde con jaspeado cuya asa es vertical, sobreelevada y más desarrollada en la parte superior (Lám. I:4), pieza que encuentra paralelos en Pechina (CASTILLO y MARTíNEZ, 1993, lám.VI, 17) y en Cartagena (MURCIA y GUILLERMO, 2003, 209-2 I0, fig. 19 , 134). Este tipo de ornamentación tiene una clara influencia oriental y se conoce también como "splashed ware" o salpicado. Está documentado en el Próximo Oriente en los siglos VIII y IX y tiene una escasa presencia en al-Andalus (TURINA, 1986, 459).

Hemos enunciado cinco ejemplos de excavaciones donde se ha documentado cerámica vidriada emiral con claros paralelos en otros 
conjuntos andalusíes, como Pechina (ACIÉN y MARTÍNEZ, 1989, 123-135; CASTILLO y MARTÍNEZ, 1993, 67-| | 6), Málaga (AClÉN et alii, 2003, 41 I-454; ÍNIGUEZ y MAYORGA, 1993, I17-138), Montefrío (Granada) (MOTOS, 1993, 203-237), el Tolmo de Minateda (GUTIÉRREZ, GAMO y AMORÓs, 2003, I 19-168), Cartagena (MURCIA y GUILLERMO, 2003, 169-223) o el Pantano de Iznájar (Granada) (CANTO y RETUERCE, 1995, 34I-350; RETUERCE y CANTO, 1987, 100-102), fechados en época emiral.

Por lo tanto, queda demostrada la presencia de vidriado emiral en los contextos cordobeses.

\section{CONTEXTUALIZACIÓN DEL HALLAZGO}

Además de estos ejemplos vamos a presentar un conjunto emiral excavado en la antigua Posada de la Herradura y que por sus características es muy interesante.

El solar de la Posada de la Herradura se sitúa en la margen derecha del río Guadalquivir y extramuros de la Medina, al sur de la vía que partía de la Puerta oriental, identificada en época omeya como Bāb al-Hadìd y en época bajomedieval cristiana como Puerta de la Piscatería (OCAÑA, 1935, I43-151;ZANÓN, 1989. 4I-5I) (Fig. 2). Se documentaron estructuras desde época tardorrepublicana hasta la actual, identificándose algunos restos de viviendas andalusíes pertenecientes al conocido arrabal del Šabulār, que aparece citado en las fuentes (IBN HAYYĀN, 200 I, I I Iv, I55r, I69r).

El conjunto que vamos a presentar a continuación procede de un contexto cerrado. Se trata de la colmatación de un pozo negro, es decir, se realizó una fosa de 0,87 × 0,52 m y una potencia de 1,62 m, que fue interpretada como letrina (MORENO, VARGAS y GARCÍA, 2006), en cuyo interior se arrojaron aquellas piezas inservibles y una vez colmatada se cerró. No se han detectado alteraciones posteriores que hayan contaminado la muestra.

\section{EL CONJUNTO DE MATERIALES}

\section{I. Cerámica sin vidriar}

En el interior del pozo se recuperaron piezas de cerámica común, como ollas de borde exvasado y moldurado (Fig. 3), con paralelos cordobeses en Šaqunda (CASAL et alii, 2005, figs. I-3) y Cercadilla (FUERTES y GONZÁLEZ, 1994, lám. I; 1996, figs. 80-81) y de diferente tradición a las marmitas del sureste peninsular (ACIÉN y MARTíNEZ, 1989, 125- I28, fig. 1:5-10); un fragmento perteneciente a un gran contenedor, de perfil recto y borde engrosado a ambos lados, que tiene dos molduras horizontales con incisiones ovaladas (Fig. 4), similar a un ejemplar documentado en Šaqunda (CASAL et alii, 2005, fig. 14).

Formas relacionadas con la contención de líquidos (Fig. 5), como la parte superior de un jarro de cuello alto y estrecho, ligeramente exvasado y borde engrosado de sección triangular. La pieza presenta una pequeña moldura bajo el borde, concreciones calcáreas en sus paredes y el arranque de un asa que nace del borde. Encontramos un jarro similar fechado en los siglos VIII-IX en Cercadilla (FUERTES y GONZÁLEZ, 1996, I45, fig. 84); otra pieza corresponde a un jarrito de paredes globulares y cuello ancho con borde sin desarrollar, el cual conserva algunos trazos verticales de pintura blanca y sus paredes exteriores aparecen ennegrecidas, con paralelos en Šaqunda (CASAL et alii, 2005, fig. 6) y Cercadilla (FUERTES y GONZÁLEZ, 1996, I49- I 52 , fig. 87); también se documentó la parte inferior de un jarrito globular pintado en rojo con un trazo horizontal que coincide con la zona de unión del galbo y el cuello que combina con varios trazos verticales y manchas; y el galbo de una miniatura que hemos identificado como un jarrito de base plana y cuerpo cilíndrico que se estrechan en la unión del cuello. Conserva el arranque de un asa y restos de pintura blanca.

Otro grupo morfológico muy abundante en este conjunto es la tapadera (Fig. 6). Algunas de ellas realizadas a mano, hecho poco común en Córdoba, donde la gran mayoría de la cerámica se elabora a torno, incluso en las producciones 
más tempranas (CASAL et alii, 2005, 210). Se han documentado dos tipos de tapaderas. Una primera de forma discoidal, con base plana, borde exvasado y labio ligeramente redondeado o apuntado y asa horizontal de cinta. En ocasiones presenta un engrosamiento en la zona de unión de la base con el cuerpo. Este tipo encuentra paralelos en Šaqunda (CASAL et alii, 2005, fig. 18) y Cercadilla (FUERTES y GONZÁLEZ, 1996, I49, fig. 86). Una variante de este tipo es la tapadera del ángulo inferior izquierdo del dibujo, de mayor tamaño y con una moldura muy marcada en la unión de la base y las paredes, las cuales están muy exvasadas. No sabemos si tendría asa porque la pieza no se ha conservado completa. El segundo tipo corresponde a una tapadera con forma de cazoleta y perfil cóncavo, que se inicia en la base y continúa hasta llegar al borde, el cual puede estar engrosado al interior o ambos lados, en este último caso con labio ligeramente triangular. Una de las tapaderas del primer tipo aparece pintada con trazos blancos en el borde y el asa (Lám. 2).

Respecto a los cuencos se han distinguido dos tipos (Fig. 7): uno de cuerpo hemisférico con variantes en el borde, que puede ser entrante o exvasado y desarrollado al exterior; un segundo tipo tiene las paredes exvasadas, de perfil troncocónico invertido, con el borde igualmente exvasado. Éste último presenta un motivo fusiforme concéntrico, a modo de hojas trenzadas, dispuesto de forma horizontal y pintado en blanco, con paralelos en Córdoba (SANTOS, 1956, 42-43, fig. 30, núm. 15).

Por último, se recuperaron dos fragmentos pintados en blanco, uno engobado en rojo con motivo zoomorfo, que representa dos patas de un ave y otro engobado en negro parece representar un motivo arquitectónico de arcos rellenos con puntos en su interior (Lám. 2). Existen paralelos cordobeses de representaciones de aves en pintura blanca y amarillenta sobre fondo rojo en un jarrito y una taza datados como califales y hallados en el Cortijo de Chinales (SANTOS, 1956, 42, fig. 29, núms. 13-14; W. AA, 1986, 63, núm. 67) y en otros fragmentos procedente de Madinat al-Zahrā' (PAVÓN, 1967, 416 , fig. I). En este momento hay una preferencia por el uso del color blanco para los motivos pintados (SANTOS, 1948, 96-106), mientras que en momentos posteriores se utiliza más el rojo o el negro.

\subsection{Cerámica vidriada monocroma y bícroma}

En el conjunto también existe cerámica vidriada. Se localizaron tres candiles vidriados en verde (Fig. 8). Uno de ellos tiene cazoleta lenticular con incisiones oblicuas y una moldura horizontal con pequeñas perlas, el asa es sobreelevada y tiene un apéndice aplicado en la parte superior de la misma (Lám. 3); un segundo candil tiene la cazoleta lenticular, que presenta una banda horizontal de pequeñas incisiones curvas, el gollete es muy corto y el borde es exvasado con moldura marcada en el interior, en la unión de la chimenea con la cazoleta. La pieza presenta un defecto en la aplicación del vidriado, hecho que podría apuntar a una producción local. Se identificó un fragmento con este tipo incisiones en el Tolmo de Minateda (GUTIÉRREZ, GAMO y AMORÓs, 2003, I56, fig. 10.16).

Un último ejemplo corresponde a un candil en miniatura que se ha conservado completo, con peana, cazoleta lenticular y piquera corta; el asa es anular parte de la zona más sobresaliente de la cazoleta y termina en la unión de la misma con la chimenea (Lám. 4).

En la siguiente figura mostramos varios fragmentos de jarritos (Fig. 9). Concretamente parte de un jarrito vidriado en tonos melados, que tiene cuerpo abombado de tendencia troncocónica, moldura escalonada en el hombro, cuello largo y exvasado y borde recto. En las paredes exteriores se aplican nervios verticales con punzamientos en el interior (Láms. 5-6); también se incluyen dos asas verticales sobreelevadas con apéndices aplicados en la parte superior, que arrancan del borde y terminan en la mitad de la pieza. Existen jarros de este tipo en Málaga (ACIÉN et alii, 2003, 420, fig. 7, nos 63, 65; ÍNIIGUEZ y MAYORGA, 1993, I 28- I 30, lám. 6), Pechina (CASTILLO y MARTíNEZ, 1993, 87-88, lám. VI) y con galbo globular en Calatrava la Vieja (RETUERCE et alii, 2009, lám. 1:6). 
Esta misma ornamentación aplicada se repite en dos cuencos hemisféricos, de paredes profundas y borde recto ligeramente apuntado, con cubierta vidriada bícroma, al interior en verde y al exterior en melado o tonos achocolatados (Fig. 10). El esquema ornamental presenta varias líneas incisas horizontales, bajo el borde, y nervios verticales aplicados "a la barbotina", que en uno de los cuencos alterna con rombos dispuestos también de forma vertical y punzamientos en el interior (Láms. 7-8). Paralelos de este tipo de ornamentación se recogen en Montefrío (MOTOS, 1993, 231, fig. 12, 2-3), el Tolmo de Minateda (GUTIÉRREZ, GAMO y AMORÓs, 2003, 156, fig. 10.10, 10.12), Calatalifa (Villaviciosa de Odón) (RETUERCE, 1998, 4I0, núm. 48I) y el Pantano de Iznájar (CANTO y RETUERCE, 1995, 34I-350; RETUERCE y CANTO, 1987, 100-102). Asimismo se documentó un cuenco vidriado en melado, de perfil hemisférico y borde ligeramente entrante, que presenta una serie de costillas realizadas a molde y dos incisiones horizontales en la parte superior (Lám. 9). Estos cuencos parecen tomar modelos de recipientes vítreos, puesto que tienen muchas similitudes con algunos ejemplares realizados a molde y hallados en Madinnat al-Zahrä' ', tanto en la forma como en las irisaciones doradas, aunque difiere en los temas ornamentales, que son mucho más simples (RONTOMÉ, 2000, 104, fig. I;WV. AA, 1986, 9 I-92, núms. I47- I 49). Dichos cuencos podrían estar copiando y por tanto sustituyendo a piezas de vidrio, que a su vez se introdujeron para suplir a la vajilla de oro y plata, en tiempos de Ziryāb (IBN HAYYĀN, 200I, I5 Iv; RONTOMÉ, 2006, I 17).

En cuanto a los ataifores se han diferenciado cinco tipos, todos sin pie (Figs. I I - |4). El primer tipo es el más profundo, con una altura de 6 $\mathrm{cm}$ y un diámetro de $19 \mathrm{~cm}$. Tiene base plana, paredes exvasadas y borde alado y desarrollado al exterior. Estamos ante una pieza con bicromía, que combina dos tipos de vidriado, verde al interior $y$ en el borde y melado para el exterior (Fig. II, Lám. I0). Existen paralelos morfológicos en Pechina (CASTILLO y MARTíNEZ, 1993, 82-86, lám. V).

El segundo grupo presenta un perfil poco profundo y paredes ligeramente exvasadas (Fig. II, Lám. II). La cubierta es monocroma, vidriada en melado, y tiene una impresión en el interior con motivos almendrados dispuestos de manera radial. Esta combinación de vidriado monocromo con motivos impresos, pero más complejos, se emplea en ataifores procedentes de Egipto y fechados a partir del 850 (PHILON, 1980, 5-33) y en Susa (Irán) ², también datados en el siglo IX.

\subsection{Cerámica vidriada polícroma}

El tercer grupo de ataifores es de base ligeramente convexa, paredes exvasadas, de perfil levemente curvo y borde sin desarrollar (Fig. II, Láms. 12-13). Son piezas de mayor diámetro, oscilando entre los 22 y $28 \mathrm{~cm}$ y presentan semejanzas con la forma de cerámica africana Hayes 62B (HAYES, 1972). Este tipo se repite en Pechina (CASTILLO y MARTíNEZ, 1993, 82-86, lám. IV). Presenta incisos dos o más círculos concéntricos en el interior y puede vidriarse en verde o melado. Uno de los ejemplares tiene manchas verdes y negras en su interior, por lo que podría tratarse de un primer ensayo del verde y morado o verde y manganeso. Este tipo de ornamentación con puntos verdes y negros sobre un fondo vidriado blanco opaco aparece en otros cuencos hallados en Siria e Iraq, los cuales siguen modelos chinos. En concreto, una de las piezas, procedente de Siria, fue fechada entre los siglos VIII y IX (WATSON, 2004, 175).

Un cuarto tipo es de base plana y tiene las paredes completamente rectas y exvasadas, de perfil troncocónico invertido, que terminan en un borde sin desarrollar (Fig. 12, Lám. 14). La forma recuerda al tipo africano Hayes 50 y es idéntica a varios ataifores de Pechina (CASTILLO y MARTíNEZ, 1993, 82-86, lám. V), incluso con dos incisiones circulares en el interior de la pieza, en

\footnotetext{
I Algunos autores proponen una manufactura autóctona para de este tipo de piezas (GÓMEZ-MORENO, 1951, 344; RONTOMÉ, 2000, II4).

2 http://commons.wikimedia.org/wiki/File:Bowl_geometric_Louvre_MAOS8I5.jpg
} 
la unión de las paredes y la base, pero la ornamentación es diferente. Se recuperaron varios fragmentos de ataifores que podrían adscribirse a este tipo. La pieza mejor conservada se halla vidriada en verdoso por ambas superficies y al interior se dibujan líneas formando retícula en verde e intercaladas con puntos en negro, a la vez que el borde está pintado en negro. Aquí tendríamos otro ejemplo de proto verde y manganeso. En Fustat (Egipto) encontramos un ataifor polícromo, datado en el siglo IX, con el fondo plumbífero melado, los trazos son simples y se dibujan con óxido de hierro negro, al igual que el borde, y se rellenan con óxido de cobre (GAYRAUD, 1997, 264, fig. 2).

En el conjunto existe un quinto tipo de ataifor que desarrolla formas hemisféricas, más cercanas a las califales y de gran diámetro (de hasta $31 \mathrm{~cm}$ ) (Figs. 13-14). Un primer ejemplo presenta en su cara interior manchas negras y meladas sobre fondo verde, mientras que el resto lo hace sobre un fondo blanco ${ }^{3}$, dibujando trazos negros, parduzcos y verdes azulados, con motivos de rombos inscritos, líneas onduladas, en zigzags u oblicuas.

Un ataifor de este tipo presenta dientes de sierra que parecen componer dos estrellas concéntricas de muchas puntas, la de mayor diámetro es de color verde y alterna con puntos negros, que a su vez es el color de la estrella interior. Separando ambas se disponen tres incisiones circulares (Fig. 14, Láms. 15-16). Otro ejemplo que alterna líneas diagonales en negro y verde. Vemos como característica común que aún el verde no rellena al negro, sino que se combinan componiendo trazos de diferentes formas.

Encontramos paralelos de ataifores hemisféricos datados como emirales en Málaga (ACIÉN et alii, 2003, 418-420, figs. 4-5; í̃̃IGUEZ y MAYORGA, 1993, 126-126, lám. 4), aunque algunos presentan pie, rasgo que no ha sido documentado en nuestro repertorio, puesto que todas las piezas, sin excepción, tienen la base plana o ligeramente convexa y carecen del mismo.
Con respecto a la técnica empleada, existen ataifores vidriados monocromos en otros lugares de al-Andalus, como Valencia (PASCUAL, RIBERA y ROSSELLÓ, 2003, I I I - I I3, fig. 33), vidriado bicromo con alternancia de verde y melado en Pechina (CASTILLO y MARTíNEZ, 1993, 103-1 08, lám. $\mathrm{XVI}$ ); ataifores vidriados con motivos geométricos en negro manganeso, que recuerdan a los diseños califales, muchos de ellos con pie y datados en época emiral, en Málaga (ACIÉN et alii, 2003, 41 8-420, figs. 4-5; í̃̃IGUEZ y MAYORGA, 1993, 126-126, lám. 4) y Pechina (CASTILLO y MARTíNEZ, 1993, 103- 108, láms. XVI-XVII); Y algunos fragmentos en verde y manganeso, que corresponden al segundo nivel de Pechina (CASTILLO y MARTíNEZ, 1993, I03-I08, láms. XVI-XVII), fechado en un periodo emiral, pero entroncando con técnicas dominantes durante el califato (CASTILLO y MARTÍNEZ, 1993, I 16). Sin embargo, éstos últimos parecen encuadrarse en un momento posterior a las nuestros, puesto que tienen pie, el borde engrosado y en algunos casos un perfil carenado y además no coinciden los motivos ornamentales.

La técnica de verde y manganeso se documenta también en otros recipientes cerámicos de nuestro repertorio, aparte de los ataifores. Forma parte del elenco este pequeño cuenco de base convexa y perfil curvo con motivo almendrado en negro y relleno con trazos diagonales en verde azulado (Fig. I5, Lám. 17). Otra pieza, que quizás esté copiando recipientes vítreos, es esta taza con dos pequeñas asas horizontales, base plana, paredes exvasadas y borde engrosado de perfil recto, en el que se disponen varias franjas horizontales de trazos verdes y negros con motivos difíciles de apreciar: una línea horizontal en verde en la parte superior, debajo de ésta hay una segunda franja con motivos pintados en negro, seguida de una con óvalos inclinados en verde y puntos inscritos en negro, y en la parte inferior una cenefa de espigas en negro (Fig. I5, Lám. 18). No hemos encontrado paralelos formales, pero podría recordar a una pieza iraní del siglo $X$ (SOUSTIEL, 1985, núm. 48); asimismo se documentó

\footnotetext{
3 Según los análisis arqueométricos realizados a algunas piezas califales de Madinnat al-Zahrā’ se trataría de un vedrío de plomo-sílice opacificado con dióxido de estaño (GONZÁLEZ et alii, 1999, II-38).
} 
la parte inferior de un jarrito de base plana y paredes globulares con motivos fusiformes concéntricos, en negro y verde, organizados en dos franjas horizontales, los cuales recuerdan al cuenco de pasta anaranjada con motivo pintado en blanco, que comentamos anteriormente (Fig. 15, Lám. 19).

La siguiente pieza podría identificarse con una taza (Fig. 16, Lám. 20). Conserva una pata en la base y el arranque de un asa, el cuerpo es cilíndrico y tiene el borde exvasado y el labio alado y engrosado al exterior. En la parte inferior se disponen una especie de gotas dibujadas en negro rellenas con tres o cuatro puntos verdes azulados en su interior. Mientras que en la zona superior se desarrollan motivos en zigzag en negro, alternando con puntos verdes.

Y por último, esta orza tiene base plana, cuerpo ovoide con asas verticales y dispuestas en la parte más sobresaliente del galbo, cuello corto y borde exvasado y engrosado al exterior (Fig. 17, Láms. 21-22). Combina incisiones en la parte superior del galbo, alternando cuatro líneas horizontales que enmarcan tres bandas onduladas, mientras que la totalidad de la pieza se cubre con trazos negros, verdes y melados, diagonales y a ráfagas, recordando a las piezas chinas T'ang (WATSON, 1984; 2004, 47). El interior de la orza está cubierto con una capa de vedrío verde. Es interesante resaltar la policromía de esta pieza concreta. Encontramos paralelos en cuanto a la forma y a la técnica incisa, pero sin vidriar en Barcelona. Los autores fechan este tipo de ollas en un arco temporal poco preciso, que abarca los siglos IX al XI (LÓPEZ et alii, 2003, 60-63, fig. X.II, 13, 15, 17). Respecto a los motivos pintados recuerda al jaspeado en verde y blanco de una jarra procedente de Samarra (NORTHEDGE, 1997, fig. 4, núm. 246) y a la ornamentación polícroma de líneas verticales de varias ollas halladas en Sirjān (MORGAN y LEATHERBY, 1987, 80, fig. 31, núms. 1-9); y para la combinación de motivos incisos lineales y ondulados, también encontramos paralelos en ollas globulares procedentes de Sirjān (MORGAN y LEATHERBY, 1987, 99, fig. 55, núms. I-8), mientras que el vidriado a ráfagas es característico de la cerámica T'ang, que llega al mundo árabe a través del comercio marítimo (BERNUS-TAYLOR, 1995, 60-61; WOOD et al., 2009).

Llama la atención la ausencia de redomas, presentes en otros contextos emirales andalusíes (CASTILLO y MARTÍNEZ, 1993, 89-93, láms. VIII-IX; Í̃NIGUEZ y MAYORGA, 1993, 126-138, lám. 5; MOTOS, 1993, 230, fig. 12).

\section{ORÍGENES, DIFUSIÓNY CEN- TROS DE PRODUCCIÓN DEL VIDRIADO ANDALUSÍ}

Los orígenes del vidriado se remontan al II milenio a.C. en Mesopotamia. En esta zona continúa el vidriado monocromo, durante los periodos parto y sasánida; con la conquista árabe, en el periodo omeya y posteriormente, durante el abbasí, se sigue produciendo esta técnica; presentando problemas de identificación la cerámica sasánida y la omeya por sus numerosas similitudes. Así, en el siglo VII y primera mitad del VIII está presente el vidriado monocromo (verde o azul) en la antigua Mesopotamia (NORTHEDGE, 1997, 213-214). El origen del vidriado islámico habría que entenderlo como una continuidad del mundo mesopotámico y no del mundo romano o bizantino. Gracias a los hallazgos arqueológicos se ha demostrado que existen varios centros islámicos productores de vidriado monocromo situados en distintos lugares del Próximo y Medio Oriente: Samarra, Fustat, Raqqa, Susa, Siraf, etc. (GAYRAUD, 1997; NORTHEDGE, 1997).

En España existe vidriado monocromo en época romana, parte del cual parece que fue producido en talleres hispanos (PAZ, 2008), pero éste no alcanza el mundo visigodo. Está comúnmente aceptada la idea de que, en algún momento del siglo IX, se trasmite la técnica del vidriado desde Oriente hasta al-Andalus, a través del comercio marítimo. No están claras las rutas orientales de difusión del vidriado hasta el Mediterráneo occidental, aunque parece que el área aglabí pudo jugar un papel importante como transmisor (ACIÉN y MARTíNEZ, 1989, 134), debido a la relación entre los baŷyāníes y los aglabíes (ACIÉN, 1993, 159). 
A mediados del siglo IX, parece que llegan a Bâ̂ỹāna (Pechina) las primeras importaciones vidriadas. A partir de la excavación de un barrio artesanal y un alfar con un horno cerámico y otro de vidrio (CASTILLO et alii, 1987), se ha planteado la hipótesis de que Pechina fuera el primer centro productor peninsular, el cual copiaría modelos orientales que llegan a la ciudad a través de los intercambios comerciales que establecen los marineros pechineros con el resto del Mediterráneo. Por tanto, en Pechina se iniciarían las primeras producciones de alAndalus y se comercializarían, principalmente en ambientes urbanos del sureste peninsular (ACIÉN, 1993). Existen otros centros productores, como Málaga o Murcia (ACIÉN, 1993, 17I). Respecto a Córdoba, la ausencia de hallazgos ha planteado, durante mucho tiempo, un gran vacío acerca de las producciones vidriadas emirales y su posterior conexión con las califales de Madinat al-Zahrā'.

Es en el siglo IX cuando se constata, igualmente, en el Próximo y Medio Oriente, el vidriado bícromo (verde y pardo) y el vidriado polícromo (NORTHEDGE, 1997, 216), que se relacionan con la dinastía T'ang ${ }^{4}$ (BERNUS-TAYLOR, 1995, 60; WOOD et al., 2009). Al igual que la producción que combina verde, pardo y negro, tiene influencias de la China T'ang (WATSON, 1984). La ornamentación de manchas en verde, melado o/y negro recuerda a algunos ataifores polícromos de Susa fechados en los siglos IX-X, de Sirjāan (Irán), algo más tardíos, fechados C. 950- I 050 (MORGAN y LEATHERBY, 1987, 79, fig. 30, núms. I-I I) y de los siglos $\mathrm{X}$-XI procedentes de Egipto (PHILON, 1980, 4I-53).

Respecto a los posibles prototipos, formales y ornamentales, que estarían copiando las piezas vidriadas cordobesas, monocromas y polícromas, encontramos algunas que tienen equivalencias solamente en Oriente, mientras que otras sí presentan analogías con piezas peninsulares. Existen paralelos morfológicos andalusíes de candiles, jarritos y ataifores, mientras que para los cuencos y las tazas no se han hallado paralelismos. En cuanto a las ornamentaciones, hay piezas peninsulares monocromas con incisiones de escamas, molduras horizontales con pequeñas incisiones y aplicación de nervios verticales y romboidales que, en algunos casos se repiten en formas distintas (véase CANTO y RETUERCE, 1995; RETUERCE y CANTO, 1987). Sin embargo, hasta el momento se desconocen otros ejemplos andalusíes de vidriados polícromos emirales. Si tenemos en cuenta el conjunto de la Posada de la Herradura y otros hallazgos vidriados emirales cordobeses, Pechina es el yacimiento con el que hemos encontrado más similitudes. Otros lugares, con menos coincidencias, serían Málaga y el Tolmo de Minateda. Llama la atención que los nervios romboidales aplicados no aparecen en Pechina, a pesar de que este motivo tiene una amplia dispersión por la mitad sur peninsular: Montefrío, el Tolmo de Minateda, Calatalifa o Iznájar.

\section{CONCLUSIONES}

Con respecto a la procedencia de las piezas presentadas pensamos que la mayoría de ellas son de producción local. Por un lado, tenemos formas de cerámica común claramente locales que encuentran paralelos con otras del mismo periodo; y por otro, el conjunto de piezas vidriadas parece responder a producciones locales que copian modelos orientales, chinos y del Próximo y Medio Oriente, en cuanto a aspectos morfológicos y técnicos. Las formas de cerámica común reflejan un momento de transición entre los primeros momentos emirales (CASAL et alii, 2005, 189-235) y la vajilla claramente califal (VALLEJO y ESCUDERO, 1999 , 133-175) con similitudes en otros conjuntos datados entre finales del siglo IX y principios del X (FUERTES y GONZÁLEZ, 1996, I49-I55). Parte del conjunto vidriado puede compararse con otros yacimientos andalusíes, como Pechina. Si bien es cierto que para otras formas, no hemos encontrado paralelos en al-Andalus y hay que ir a buscarlos a Oriente. 
La coloración y naturaleza de las pastas está en consonancia con la funcionalidad de la pieza. Así, en líneas generales, las pastas de cocción reductora -grises, negras o castañas oscurasse relacionan con un uso de almacenamiento, auxiliar o culinario; y el tamaño y la cantidad de desgrasantes son mayores que en aquellas formas destinadas al servicio de mesa, de pastas claras -naranjas o beiges-, muy depuradas y cocidas en ambientes oxidantes ${ }^{5}$.

Se realizaron análisis petrólógicos ${ }^{6}$ de algunas de las piezas vidriadas. En concreto, de un fragmento de un posible ataifor bícromo (verde al interior y melado oscuro al exterior), un ataifor polícromo del tipo $\mathrm{IV}$, una taza polícroma (Fig. 16, Lám. 20) y una orza polícroma (Fig. 17, Láms. 21-22). Se concluyó que las pastas son rojizas de tipo micro-criptocristalino, en cuya composición se incluyen microcristales de cuarzo, con un diámetro medio de 0,05 $\mathrm{mm}$. Además, se compararon con otras piezas cerámicas procedentes de fallos de cocción de un alfar almohade, ubicado en Córdoba, y se comprobó que la composición era la misma. Estos datos apoyan una procedencia local.

Sobre los aspectos tecnológicos, algunas de las piezas presentan pequeños defectos, como consecuencia de haberse pegado a otros recipientes durante el proceso de cocción; o en otros casos la aplicación del vidriado presenta burbujas o zonas muy densas formando gotas en relieve, como si esta aplicación no hubiera sido uniforme. Estas imperfecciones parecen identificarse más con producciones locales, que con una importación o comercio de las piezas. Puesto que, si hubieran sido traídas desde Oriente u otros lugares de al-Andalus, probablemente no presentarían estos fallos tecnológicos, que habría que relacionarlos más con producciones experimentales cordobesas, que el artesano todavía no domina del todo.
Aunque todo esto son hipótesis hasta que no se localicen los talleres con los defectos de cocción.

Se han documentado algunos fragmentos de ataifores en verde y manganeso en el nivel II de Pechina ${ }^{7}$ y en melado y manganeso de Málaga, datados en época emiral, pero no se han encontrado paralelos en al-Andalus de motivos pintados en verde y negro sobre fondo verde, ni verde-melado-negro sobre fondo blanco. Tampoco se ha documentado el empleo de estas técnicas, durante el emirato, en otras formas, como tazas u orzas. Hecho que apunta a una producción local del conjunto presentado.

Para los motivos ornamentales podemos establecer varios grupos. Los pintados se realizan mayoritariamente en blanco y en uno de los casos en rojo. Son de tipo geométrico (lineales, puntos y fusiformes), zoomorfo (ave) y arquitectónico (arcos). Esta técnica se combina con un engobe en rojo o negro. La técnica incisa se emplea, normalmente en combinación con otra, para trazar líneas horizontales, puntos y en una de las piezas bandas onduladas. En menor medida se emplea el moldeado, en el ataifor tipo II y en uno de los candiles. En las piezas vidriadas se reduce a la aplicación de nervios verticales o formando rombos. Con respecto a aquellos motivos dibujados en óxido de cobre verde o negro manganeso, la mayoría son de tipo geométrico (rombos, lineales, zigzags, ondulados, puntas de estrellas...), en uno de los casos, el motivo fusiforme concéntrico es el mismo que en otra pieza pintada en blanco y hay un posible elemento epigráfico. Para la mayoría no hemos encontrado paralelos, ni siquiera en época califal (CANO, 1996; ESCUDERO, 1991, |27-161). Probablemente algunos copien modelos orientales. Lo que no hay duda es que no perduran en la etapa posterior, al contrario de lo que sucede con las ornamentaciones de

5 Estas mismas pautas se repiten en el conjunto emiral de Šaqunda (CASAL et alii, 2005, 21 I). Sin embargo, en Córdoba, en momentos posteriores deja de fabricarse cerámica en ambientes reductores, siendo casi exclusiva la cocción oxidante.

6 La composición coincide con los afloramientos que se sitúan en dos franjas al norte y sur de Córdoba y discurren paralelos al río Guadalquivir. Agradecemos la ayuda prestada en la realización de los análisis a D. Alfredo Aparicio Yagüe.

7 Mientras que al primer nivel se le asigna una cronología emiral, el segundo no tiene una adscripción cronológica clara "debemos incluir este segundo nivel en un contexto cultural donde cerámicas de época emiral se asocian a técnicas decorativas nuevas que serán dominantes durante el período califal" (CASTILLO y MARTíNEZ, I993, I I6). 
los ataifores de Málaga, con motivos de ovas y líneas onduladas (ACIÉN et alii, 2003, 418-420, figs. 4-5), que permanecen en los ataifores califales de Madinat al-Zahrā'. (CANO, 1996; ESCUDERO, 1991, 127-161). Esto puede estar indicando que nuestras piezas pertenezcan a un momento más temprano. Otro hecho interesante es que no se ha documentado en el conjunto vidriado melado y manganeso, lo que puede deberse a una razón cronológica o a que este tipo de producción sea pechinera y al principio los talleres cordobeses no la incluyan en su repertorio. Aunque a partir del califato sí se utiliza, a menudo, en redomas y sobre todo ataifores, perdurando hasta época almohade. En definitiva, los motivos ornamentales son muy simplistas, máxime si las comparamos con piezas orientales de este periodo, característica ésta que vuelve a apuntar hacia una producción local.

Hasta el momento no se han encontrado otros ejemplos de vidriado polícromo o verde y manganeso en el territorio peninsular, con una datación emiral clara. Los únicos paralelos anteriores o coetáneos al material presentado hay que buscarlos en Oriente. Por lo que habría que plantear una ruta de trasmisión similar a la del vidriado monocromo, desde Oriente a la Península, pocos años después de la llegada del primero al mundo andalusí. Tampoco se conoce cómo surge el verde y manganeso califal, tradicionalmente ligado a las producciones palatinas de Madinat al-Zahrā'. Se puede apreciar una evolución de este primer verde y manganeso tardoemiral, en el que el verde aún no rellena al negro y que tiene conexiones con el mundo oriental. Estas piezas del pozo de la Posada de la Herradura influyen en ulteriores producciones califales. Si comparamos los materiales polícromos del conjunto aquí presentado con otras cerámicas califales cordobesas procedentes de uno de los arrabales orientales, encontramos pervivencias de estos trazos verticales verdes y negros en tazas, redomas y orcitas (BAREA, 20।0, Fig. 6). Esto podría considerarse otra evidencia más de la producción local de este primer vidriado polícromo o verde y manganeso cordobés, que continúa en algunos tipos califales cordobeses, a pesar de que finalmente se impusiera el verde como relleno de los motivos dibujados en negro, elementos éstos característicos del programa ornamental del califato, en la segunda mitad del $X$.

Respecto a la cronología que proponemos para el conjunto estaría en la transición del siglo IX al $X$. En Córdoba no hay vidriado antes del 818 d.C. Lo sabemos porque se han excavado $10.000 \mathrm{~m}^{2}$ del arrabal de Šaqunda y no se ha hallado un solo fragmento vidriado. Por otro lado, en el conjunto apareció un felús en muy mal estado de conservación, del tipo Frochoso I-I (FROCHOSO, 200 I), que corresponde a una emisión del emirato independiente, posiblemente de tiempos de 'Abd al-Rahmān II (822-852), lo que nos está marcando el término postquem ${ }^{8}$. Si tenemos en cuenta que la cerámica vidriada más temprana en al-Andalus se fecha hacia el año 850, podríamos encuadrar el conjunto unos años antes de la proclamación del califato, probablemente bajo el emirato de 'Abd Allāh (888-9|2). Pudiera ser que en un momento impreciso de la segunda mitad del siglo IX, algunos artesanos se trasladen a Córdoba, procedentes de Pechina, y una vez establecidos en la futura capital del Califato comiencen a fabricar vidriado monocromo y a experimentar, a su vez, con producciones, formas y técnicas, que en parte copian modelos orientales, pero que combinan con motivos ornamentales más simples y una técnica aún por perfeccionar, hasta llegar a las producciones verde y manganeso de época califal. En este contexto podría situarse el comienzo del vidriado polícromo en al-Andalus que, a partir de los hallazgos aquí presentados, pudo fabricarse en Córdoba. A falta de los pertinentes hallazgos de alfares emirales cordobeses que confirmen esta hipótesis, tendremos que conformarnos con los análisis de pastas de algunas piezas, que avalan una producción local.

8 Agradecemos a Dña. Fátima Martín Escudero la ayuda prestada en la identificación del felús. 


\section{BIBLIOGRAFÍA}

ACIÉN, M. y MARTíNEZ, R. (1989): "Cerámica islámica arcaica del sureste de al-Andalus", Boletín de Arqueología Medieval, 3, pp. I23-I35.

ACIÉN ALMANSA, M. et alii (2003): "Cerámicas tardorromanas y altomedievales en Málaga, Ronda y Morón", en Anejos de AespA, XXVIII. Cerámicas tardorromanas y altomedievales en la Península Ibérica. Ruptura y continuidad (II Simposio de Arqueología. Mérida, 200 I), pp. 4I I-454.

BAREA PAREJA, V. (20 I 0): "Un sector del arrabal oriental en la Córdoba califal. Propuesta de tipología cerámica", en Antiquitas, 22, pp. I59-182.

BERNUS-TAYLOR, M. (1995): "La céramique de l'orient musulman des premiers siècles de l'Ilam", en Le Vert et le Brun: De Kairouan à Avignon, céramiques du Xe au XVe siècle. Marsella, 59-68.

CANO PIEDRA, C. (1996): La cerámica verde-manganeso de Madinat al-Zahrā'. Granada.

CANTO GARCÍA, A. y RETUERCEVELASCO, M. (1995): "Cerámicas y monedas andalusíes: un modelo de datación en época emiral" I Congresso de Arqueologia Peninsular. Oporto (Portugal). (Octubre, 1993). Trabalhos de antropologia e etnologia, 35 (2), 34 I-350. Oporto, pp. 34 I-350.

CASAL GARCÍA, Ma T. et alii (2005): "Aproximación al estudio de la cerámica emiral del arrabal de Šaqunda (Qurțuba, Córdoba)", en Arqueología y Territorio Medieval, 12.2, pp. 189-235.

CASTILLO, F., MARTíNEZ, R. y ACIÉN, M. (1987): "Urbanismo e industria en Bayyana. Pechina (Almería)", en Actas del II C.A.M.E., II. Madrid, pp. 539-548.

CASTILLO GALDEANO, F. y MARTÍNEZ MADRID, R. (1993):"Producciones cerámicas en Bayyana" en I Encuentro de Arqueología y Patrimonio. La cerámica altomedieval en el sur de al-Andalus. Salobreña, 1990. Granada, pp. $67-116$.

ESCUDERO ARANDA, J. (199|): "La cerámica decorada en "verde y manganeso" de Madinat al-Zahra", en Cuadernos de Madinat al-Zahrā' 2, 1988-90, pp. |27-161.

FROCHOSO SÁNCHEZ, R. (200I): Los feluses de alAndalus. Madrid.

FUERTES SANTOS, Ma C. y GONZÁLEZ VIRSEDA, M. (1994): "Nuevos materiales cerámicos emirales de Cercadilla (Córdoba): ensayo tipológico", en Anales de Arqueología Cordobesa, 5, pp. 277-301.

FUERTES SANTOS, Ma C. y GONZÁLEZ VIRSEDA, M. (1996): "Materiales de época medieval", en HIDALGO, R. et alii. El Criptopórtico de Cercadilla. Análisis arquitectónico y secuencia estratigráfica. Sevilla, pp. I19-167.

FUERTES SANTOS, Ma C. e HIDALGO PRIETO, R. (2003): "Cerámicas tardorromanas y altomedievales de Córdoba", en Anejos de AespA, XXVIII. Cerámicas tardorromanas y altomedievales en la Península Ibérica. Ruptura y continuidad (II Simposio de Arqueología. Mérida, 200 I), pp. 505-540.
GAYRAUD, R.-P. (1997): "Les céramiques égyptiennes à glaçure, IXe-Xlle siècles", en VI C.I.C.M.M.O., Aix-enProvence, pp. 261-270.

GÓMEZ-MORENO, M. (195I): El arte árabe español hasta los almohades. Arte mozárabe. Ars Hipaniae, IIII. Madrid.

GONZÁLEZ GARCÍA, F. et alii (1999): "Estudio arqueométrico de piezas cerámicas de Madinat al-Zahra", en Cuadernos de Madinat al-Zahrä', 4, pp. II-38.

GUTIÉRREZ, S., GAMO, B. y AMORÓS, V. (2003): "LOS contextos cerámicos altomedievales del Tolmo de Minateda y la cerámica altomedieval en el sudeste de la Península Ibérica", en Anejos de AespA, XXVIII. Cerámicas tardorromanas y altomedievales en la Península Ibérica. Ruptura y continuidad (II Simposio de Arqueología. Mérida, 2001), pp. I19-168.

HAYES, J. (1972). Late Roman Pottery. London.

IBN HAYYĀN (200I): Crónica de los emires Alhakam I y 'Abdarrahmān II entre los años 796 y 847 [Almuqtabis II- I]. Trad. de Maḥmūd 'Alī Makkī y Federico Corriente. Zaragoza.

î̃IGUEZ SÁNCHEZ, M. C. y MAYORGA MAYORGA, J. F. (1993): "Un alfar emiral en Málaga", en I Encuentro de Arqueología y Patrimonio. La cerámica altomedieval en el sur de al-Andalus. Salobreña, 1990. Granada, pp. I17-I38.

LÓPEZ MULLOR, A. et alii (2003): "Cerámica tardorromana y altomedieval en la provincia de Barcelona. Siglos VIIX", en Anejos de AespA, XXVIII. Cerámicas tardorromanas y altomedievales en la Península Ibérica. Ruptura y continuidad (II Simposio de Arqueología. Mérida, 200 I), pp. 4I-65.

MORENO, M., VARGAS, S. y GARCÍA, S. (2006): Informe Memoria de la Supervisión Arqueológica en la Antigua Posada de la Herradura. Córdoba, inédito.

MORGAN, P. y LEATHERBY, J. ( 1987): "Excavated Ceramics from Sïrjān", en Allan, J. \& Roberts, C. (eds.): Syria and Iran. Three Studies in Medieval Ceramics. Oxford, pp. 23- 174

MOTOS GUIRAO, E. (1993): "La cerámica altomedieval de "El Castillón" (Montefrío, Granada)", en I Encuentro de Arqueología y Patrimonio. La cerámica altomedieval en el sur de al-Andalus. Salobreña, 1990. Granada, pp. 207-237.

MURCIA MUÑOZ, A. J. y GUILLERMO MARTÍNEZ, M. (2003): "Cerámicas tardorromanas y altomedievales procedentes del Teatro romano de Cartagena", en Anejos de AespA, XXVIII. Cerámicas tardorromanas y altomedievales en la Península Ibérica. Ruptura y continuidad (II Simposio de Arqueología. Mérida, 200 I), pp. 169-223.

NORTHEDGE, A. (1997): "Les origines de la céramique à glacure polychrome dans le monde islamique", en VI C.I.C.M.M.O., Aix-en-Provence, pp. 21 3-223.

OCAÑA JIMÉNEZ, M. (1935): "Las puertas de la medina de Córdoba", Al-Andalus, III, pp. |43-I5|.

PASCUAL, J., RIBERA, A. V. y ROSSELLÓ, M. (2003): "Cerámicas de la ciudad de Valencia entre la época visigoda y omeya (siglos VI-X)", en Anejos de AespA, XXVIII. Cerámicas tardorromanas y altomedievales en la Península Ibérica. Ruptura y continuidad (II Simposio de Arqueología. Mérida, 200I), pp. 67-117. 
PAVÓN MALDONADO, B. (1967): "Notas sobre la cerámica hispanomusulmana", en Al-Andalus, $X X X \mid l$, fasc. 2, pp. 4I5-437.

PAZ PERALTA, J. A. (2008): "La producción de cerámica vidriada", en Cerámicas hispanorromanas: un estado de la cuestión. Cádiz, pp. 489-496.

PHILON, H. (1980): Early Islamic Ceramics: Ninth to Late Twelfht Centuries. London.

RETUERCEVELASCO, M. (1998): La cerámica andalusí de la Meseta, 2 tomos, Madrid.

RETUERCEVELASCO, M. y CANTO GARCÍA, A. (1987): "Apuntes sobre la cerámica emiral a partir de dos piezas fechadas por monedas", en II C.A.M.E., vol. 3, pp. 93- 104.

RETUERCE, M., HERVÁS, M. A. y DE JUAN, A. (2009): "La cerámica islámica de Calatrava la Vieja y Alarcos. Nuevos hallazgos", en VIII C.I.C.M.M.O. Ciudad Real, pp. 729-758.

RONTOMÉ NOTARIO, E. (2000): "Vidrios califales de Madinat al-Zahrā'”, en Cressier, P. (ed.): El vidrio en alAndalus. Madrid, pp. I03-I I 5.

RONTOMÉ NOTARIO, E. (2006): "Vidrio con decoración a molde", en "Catálogo" de Vidrio islámico en al-Andalus. Cuenca, pp. 92-|6|.

SANTOS GENER, S. de los (1948): "Cerámica pintada musulmana", en M.M.A.P., VIII, 1947, pp. 96- 106.

SANTOS GENER, S. de los (1956): "Adquisiciones del Museo Arqueológico de Córdoba. Cultura hispanomusulmana", en M.M.A.P., XIII, I 952, pp. 4I-44.
SERRANO PEÑA, J. L. y CASTILLO ARMENTEROS, J. L. (1992): "Excavación arqueológica de urgencia en el solar de la Plaza Mármol de Bañuelos s/n y calle San Álvaro num. 8 de Córdoba", en Anuario Arqueológico de Andalucía, 1990, tomo III, pp. 88-97.

SOUSTIEL, J. (1985): La céramique islamique, le guide du connaisseur. París.

TURINA GÓMEZ, A. (1986): "Algunas influencias orientales en la cerámica omeya andalusî", en II C.I.C.M.M.O., Toledo, pp. 455-459.

VALLEJO TRIANO, A. y ESCUDERO ARANDA, I. ( 1999): "Aportaciones para una tipología de la cerámica común califal de Madinat al-Zahra", en Arqueología y Territorio Medieval, 6. Actas del Coloquio La cerámica andalusí. 20 años de investigación arqueológica. Jaén, 15 al 17 de octubre 1997, pp. 133-175.

WATSON, O. (1984): T'ang and Liao Ceramics. New York. WATSON, O. (2004): Ceramics from Islamic Lands. New York.

WOOD, N., DOHERTY, C. y ROSSER-OWEN, M. (2009): "A technological study of Iraqu imitations of Chinese Changsha wares and Chinese Sancai wares found at Samarra", en Gu Taoci Kexue Jishu 8. ISAC, Beijing, pp. |54-| 80.

W.AA. (1986): Exposición "La Mezquita de Córdoba: siglos VIII al XV'. XI Centenario de la Mezquita. Córdoba.

ZANÓN, J. (1989): Topografía de Córdoba almohade a través de las fuentes árabes. Madrid. 
Fig. I. Plano de Córdoba con la situación de los hallazgos de vidriados emirales: I. Cercadilla.

2. Mármol de Bañuelos. 3. Ollerías. 4. $M^{a}$ Auxiliadora. 5. Patio de Mujeres del Alcázar.

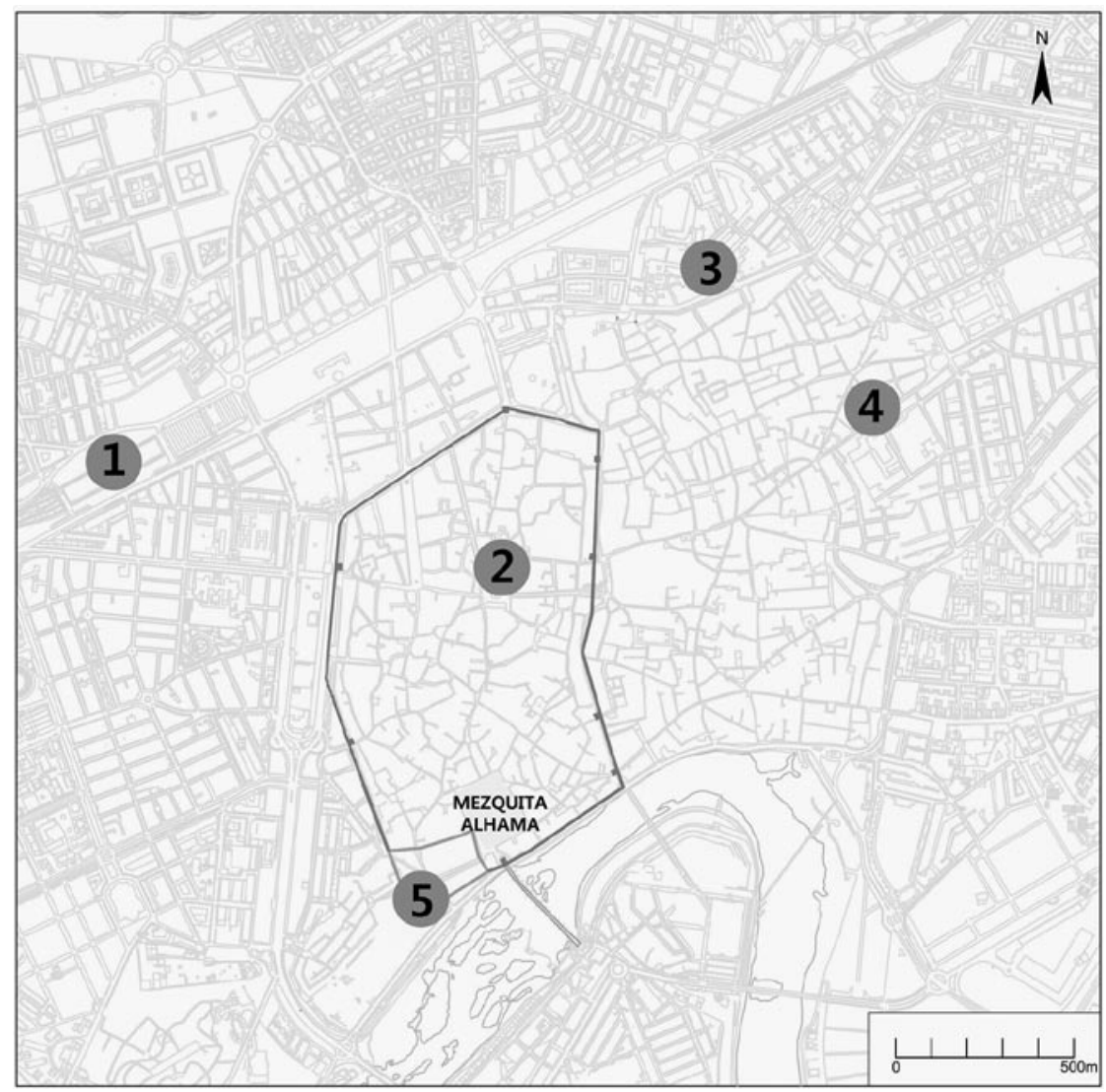

Fig. 2. Plano de situación del hallazgo de la Posada de la Herradura con respecto a la Medina.

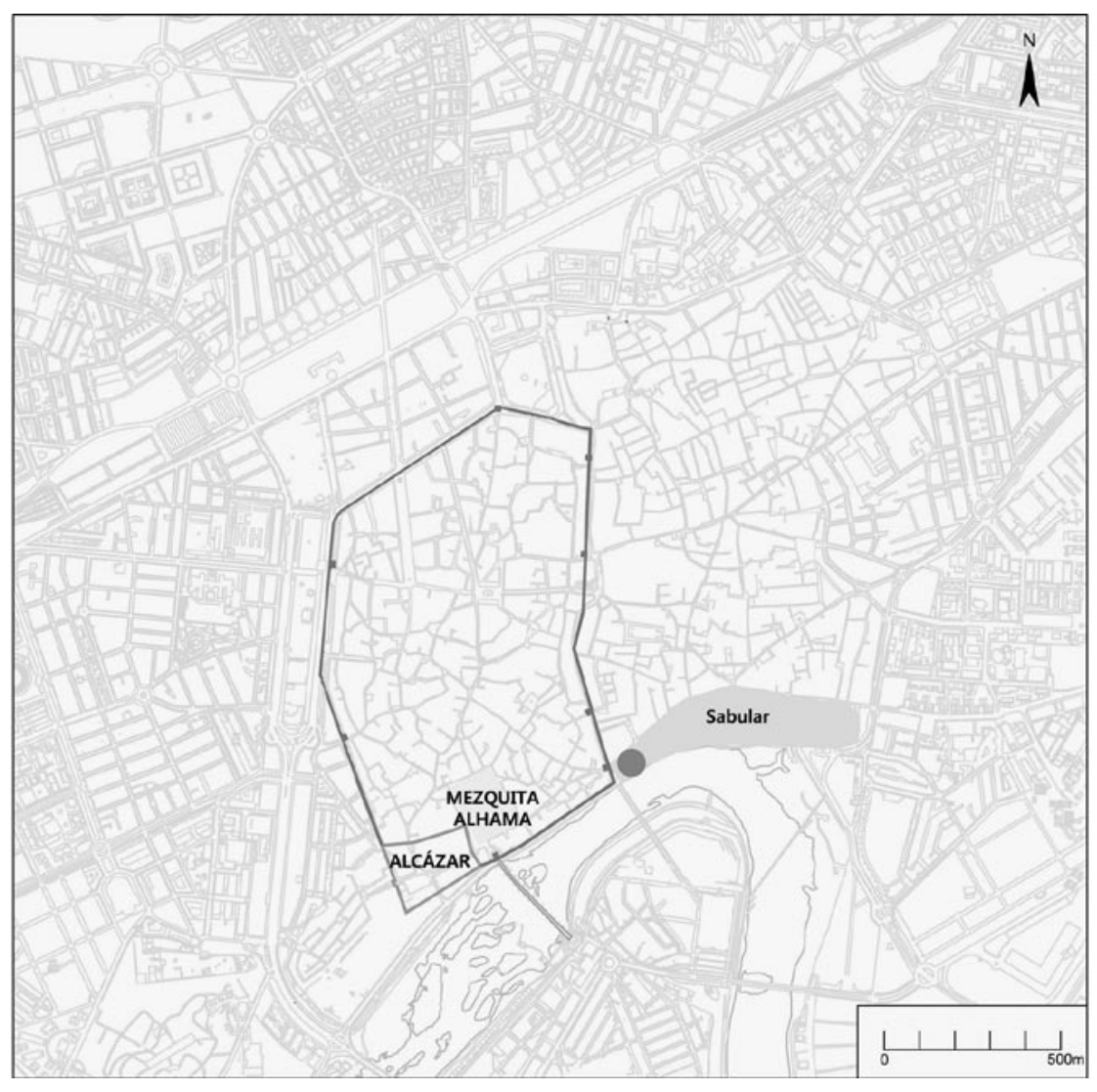




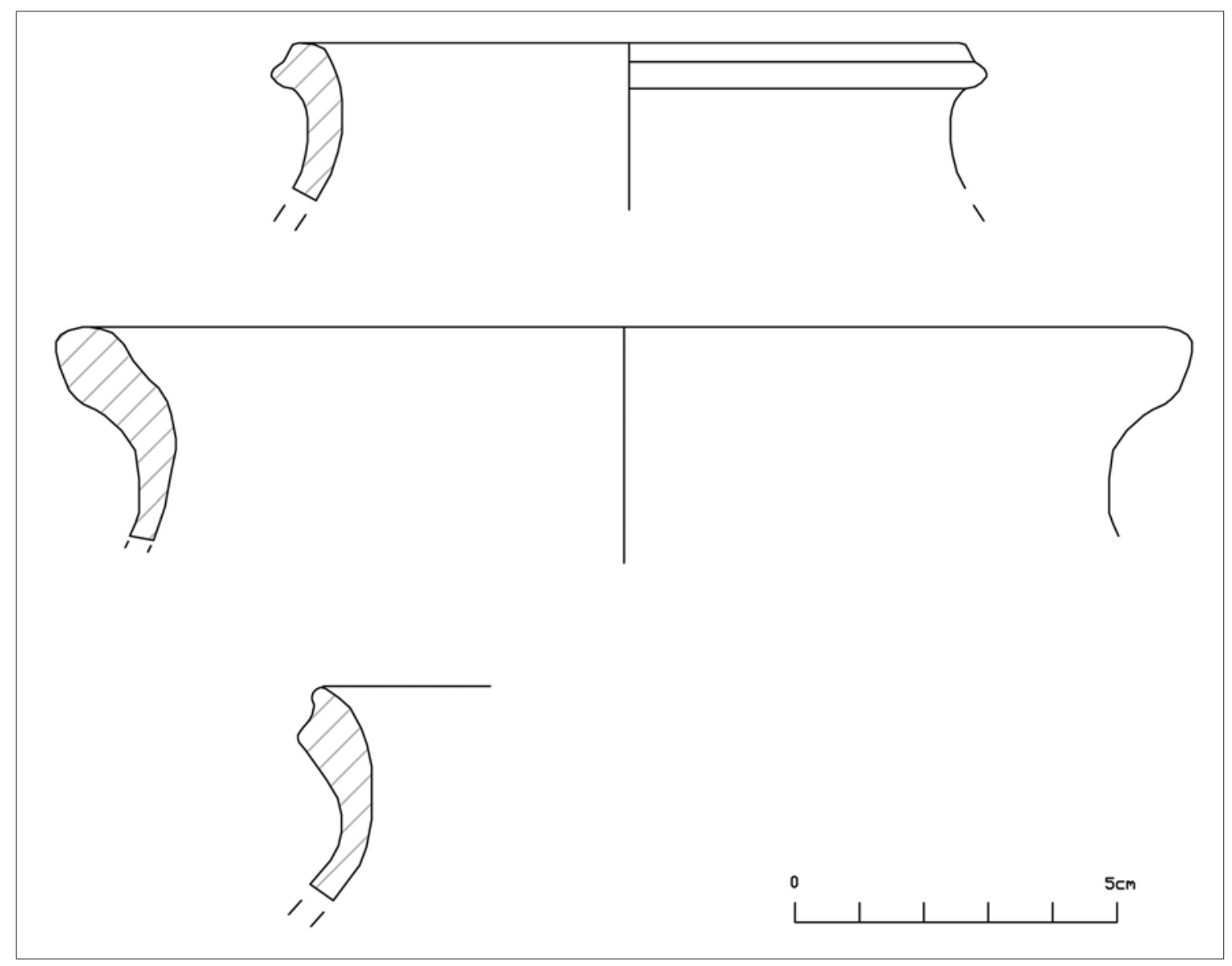

Fig. 3. Cerámica sin vidriar. Ollas.

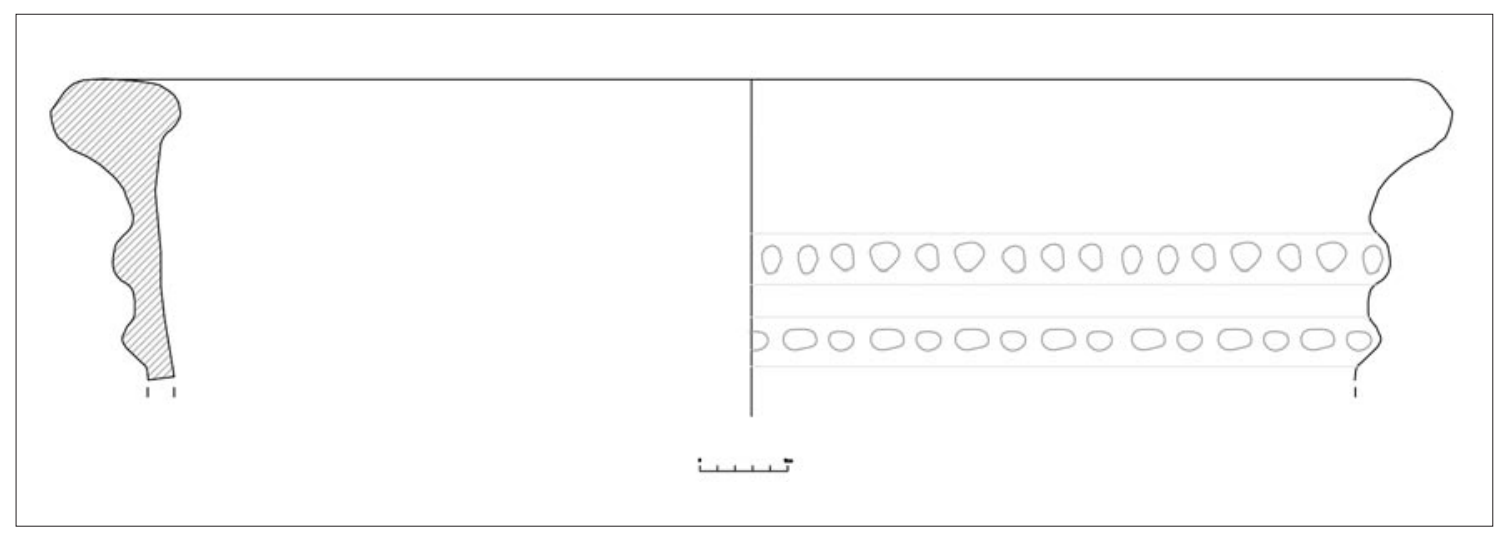

Fig. 4. Cerámica sin vidriar. Gran contenedor. 


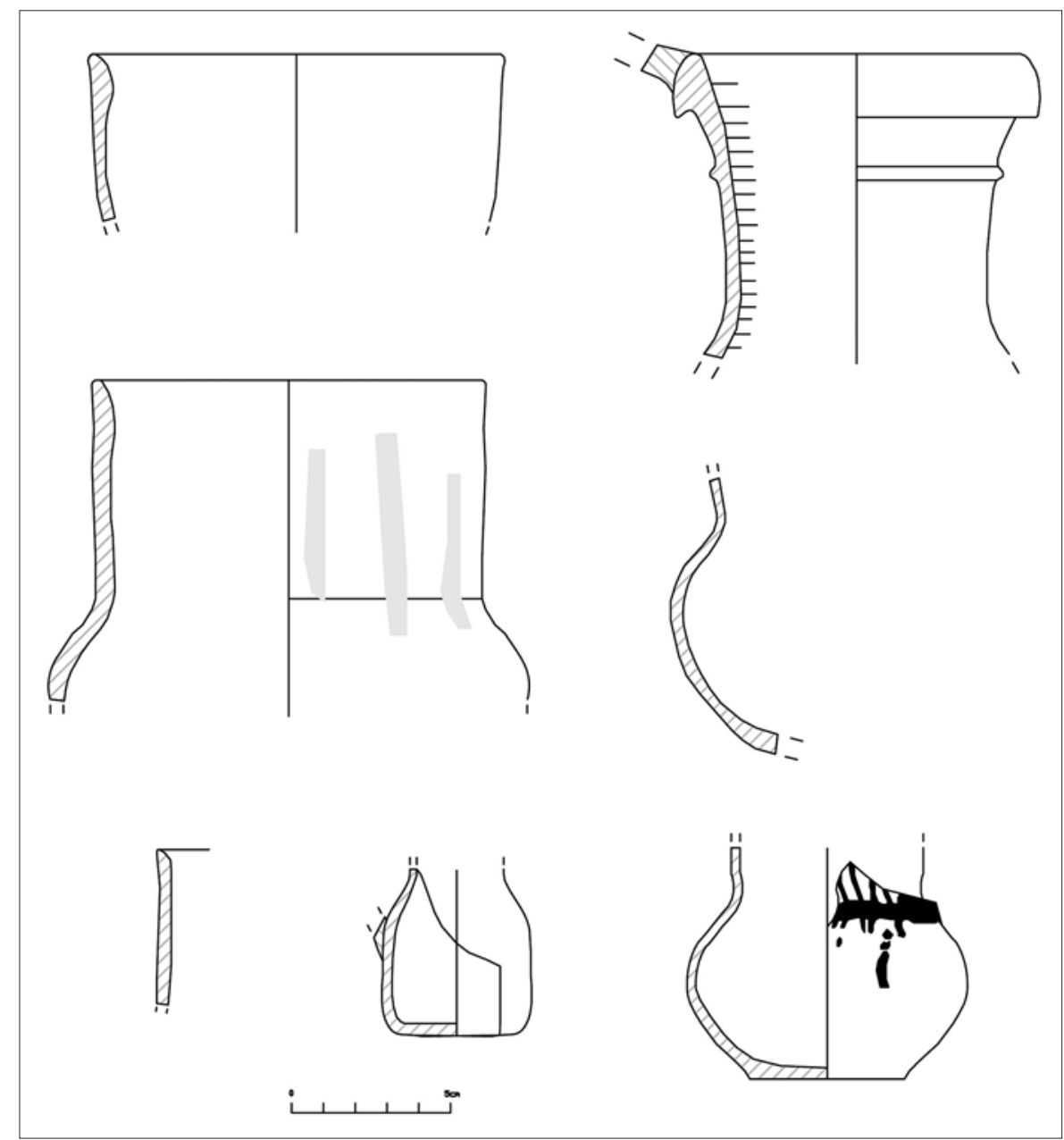

Fig. 5. Cerámica sin vidriar. Jarros/jarritos.

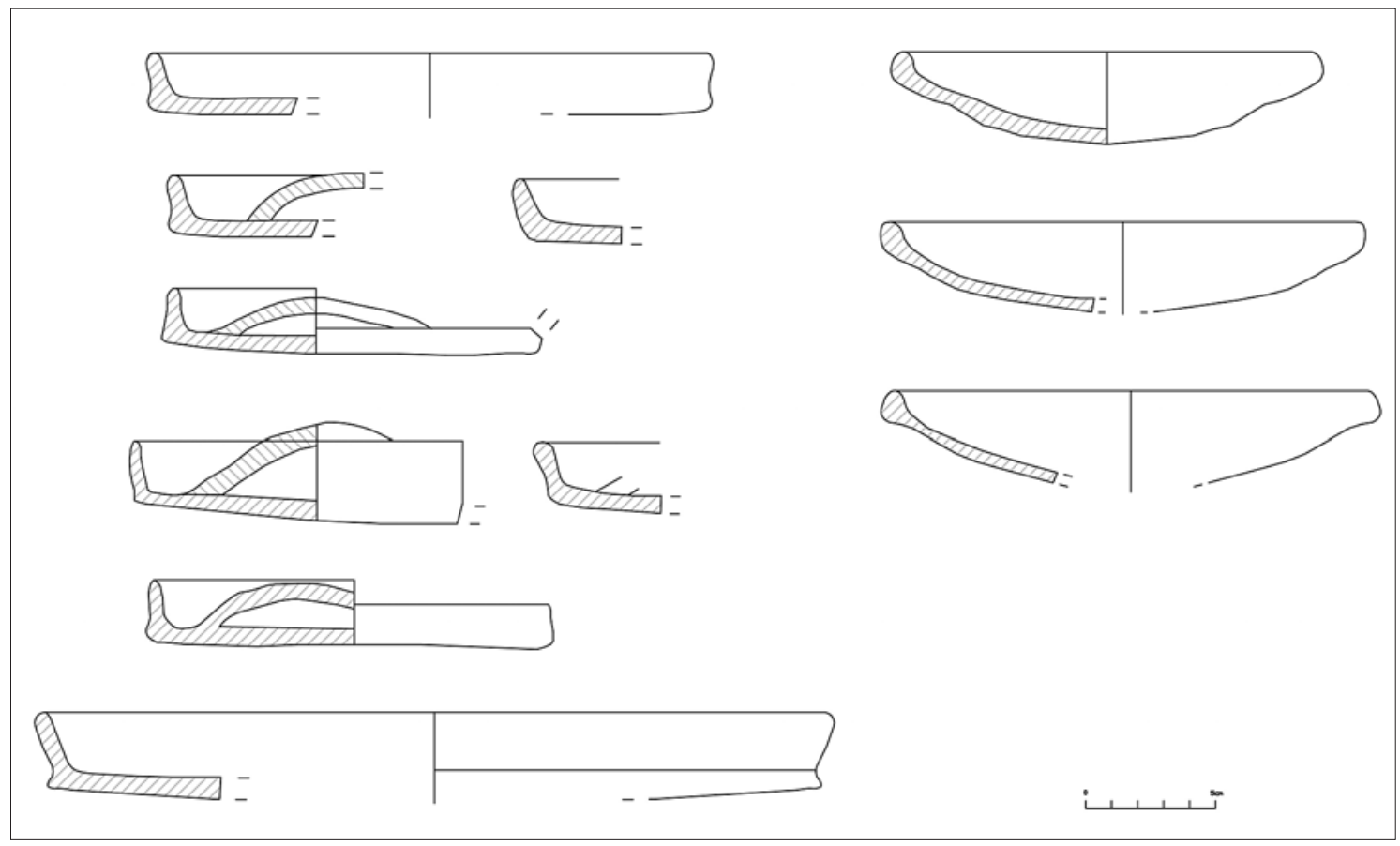

Fig. 6. Cerámica sin vidriar. Tapaderas. 


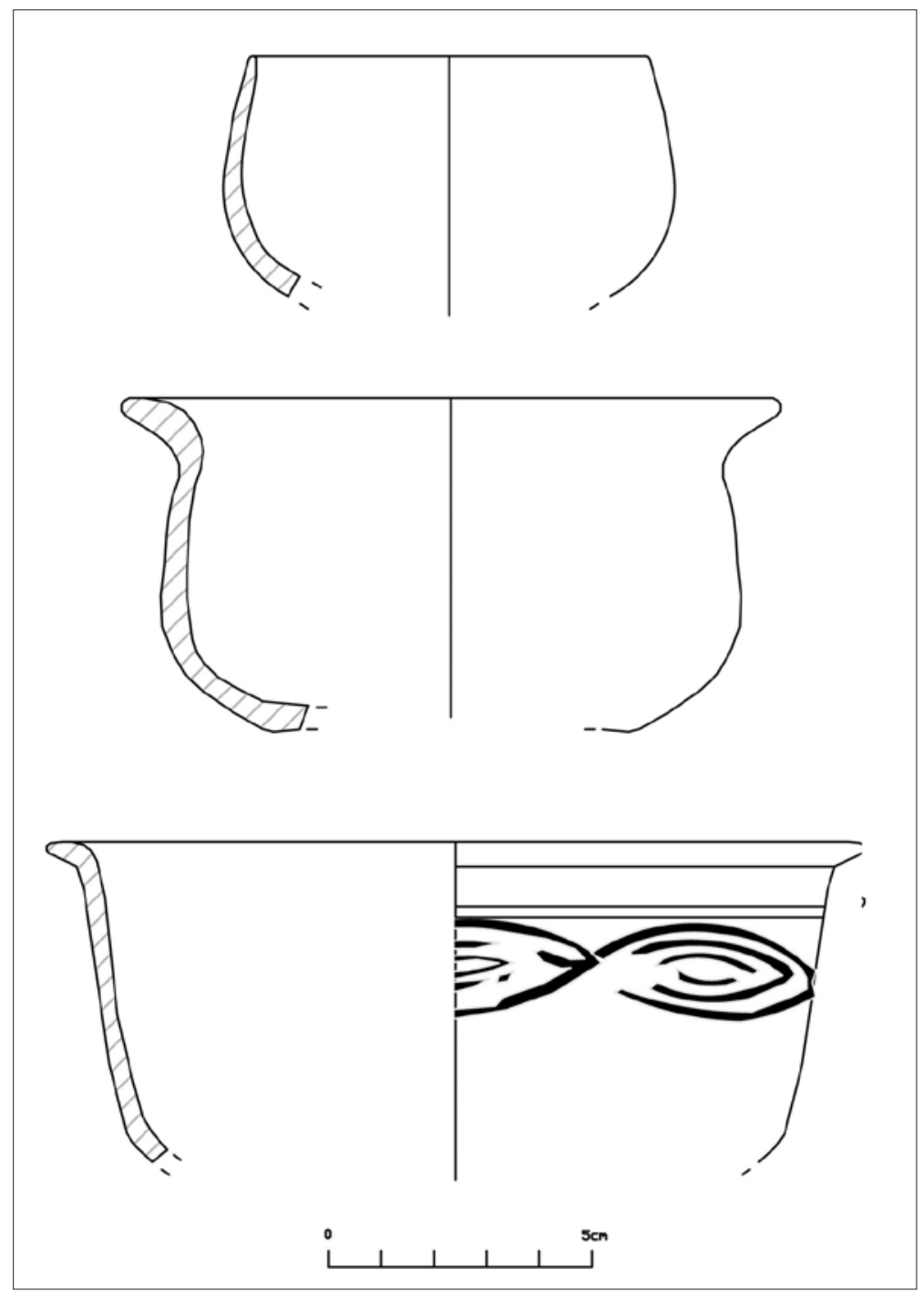

Fig. 7. Cerámica sin vidriar. Cuencos.

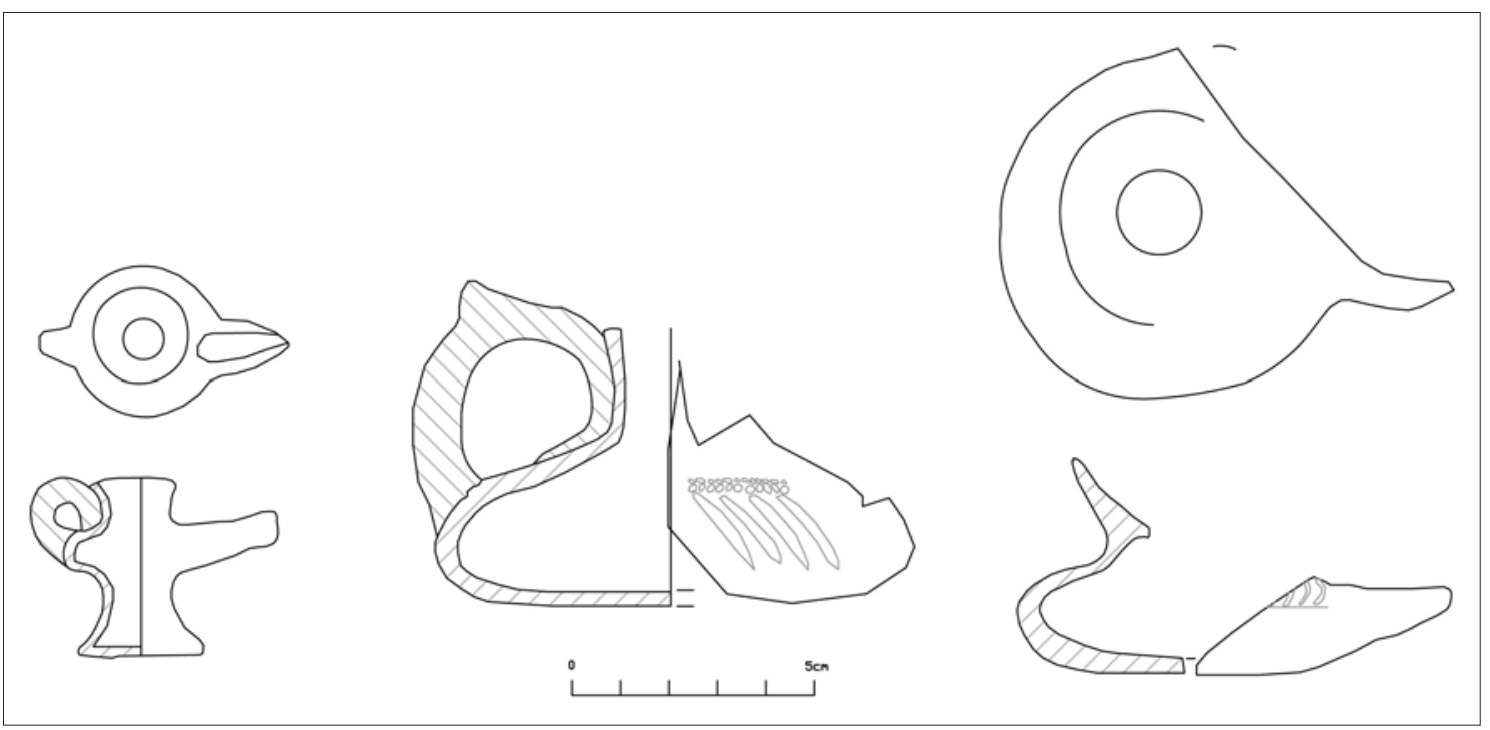

Fig. 8. Cerámica vidriada. Candiles. 


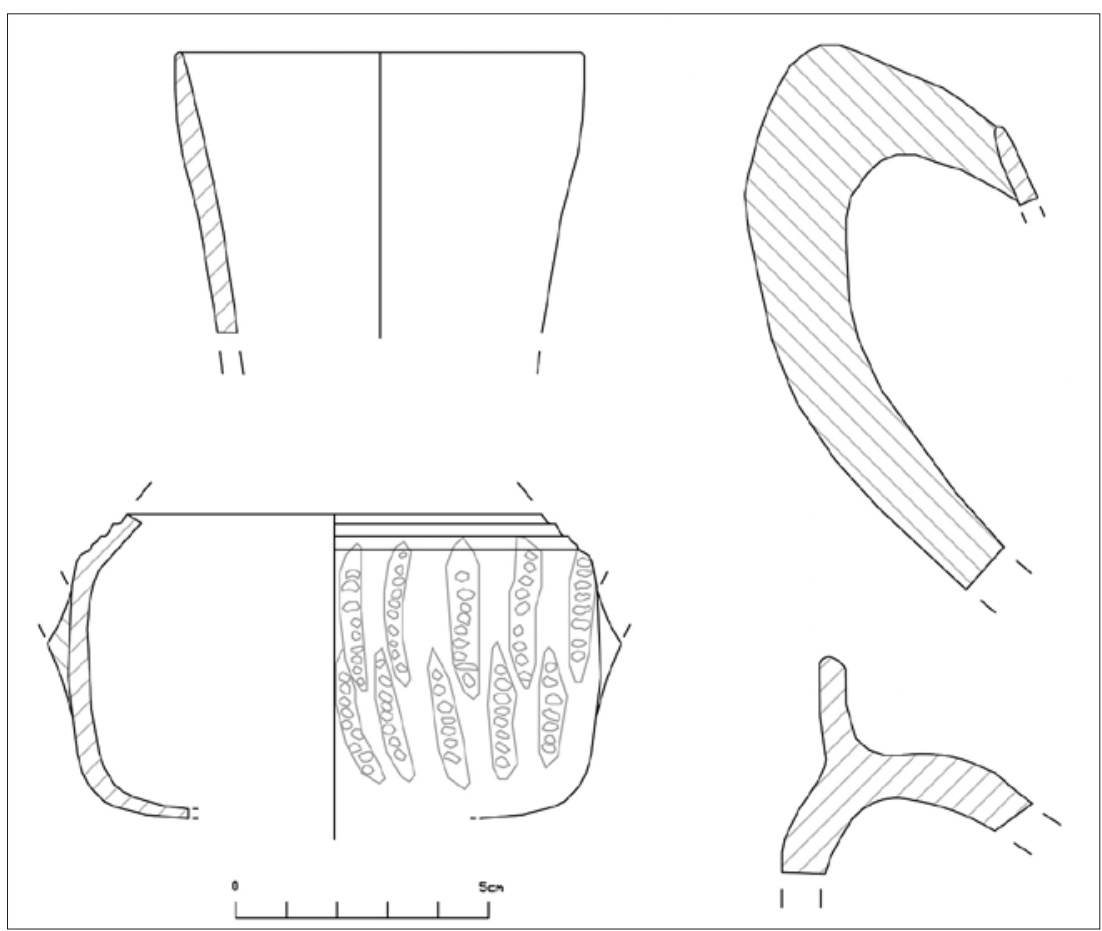

Fig. 9. Cerámica vidriada. Jarritos.

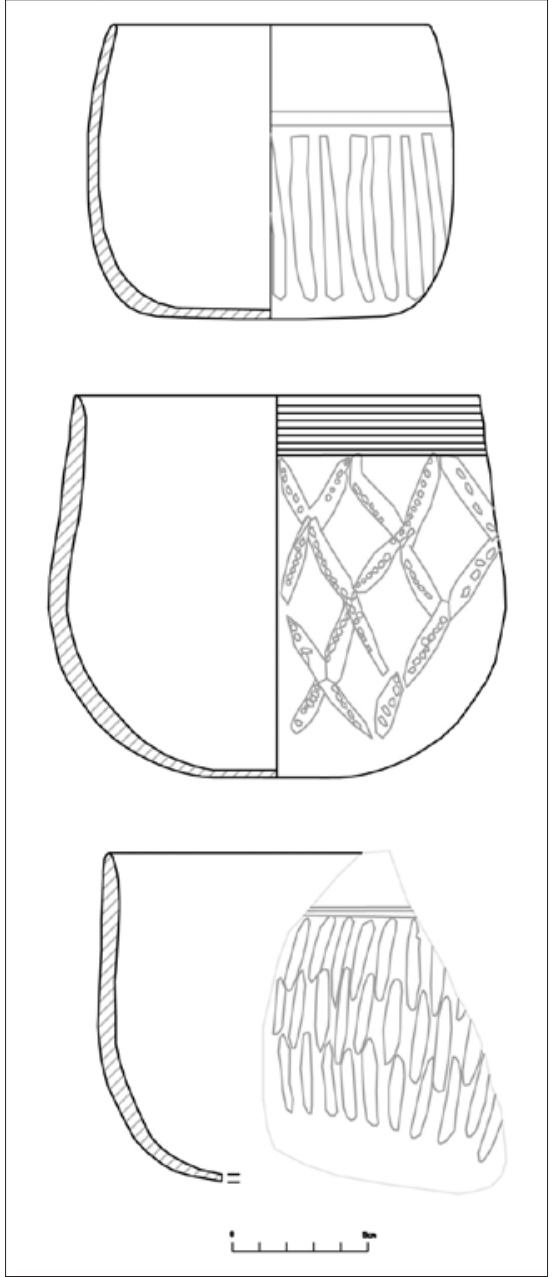

Fig. I0. Cerámica vidriada. Cuencos.

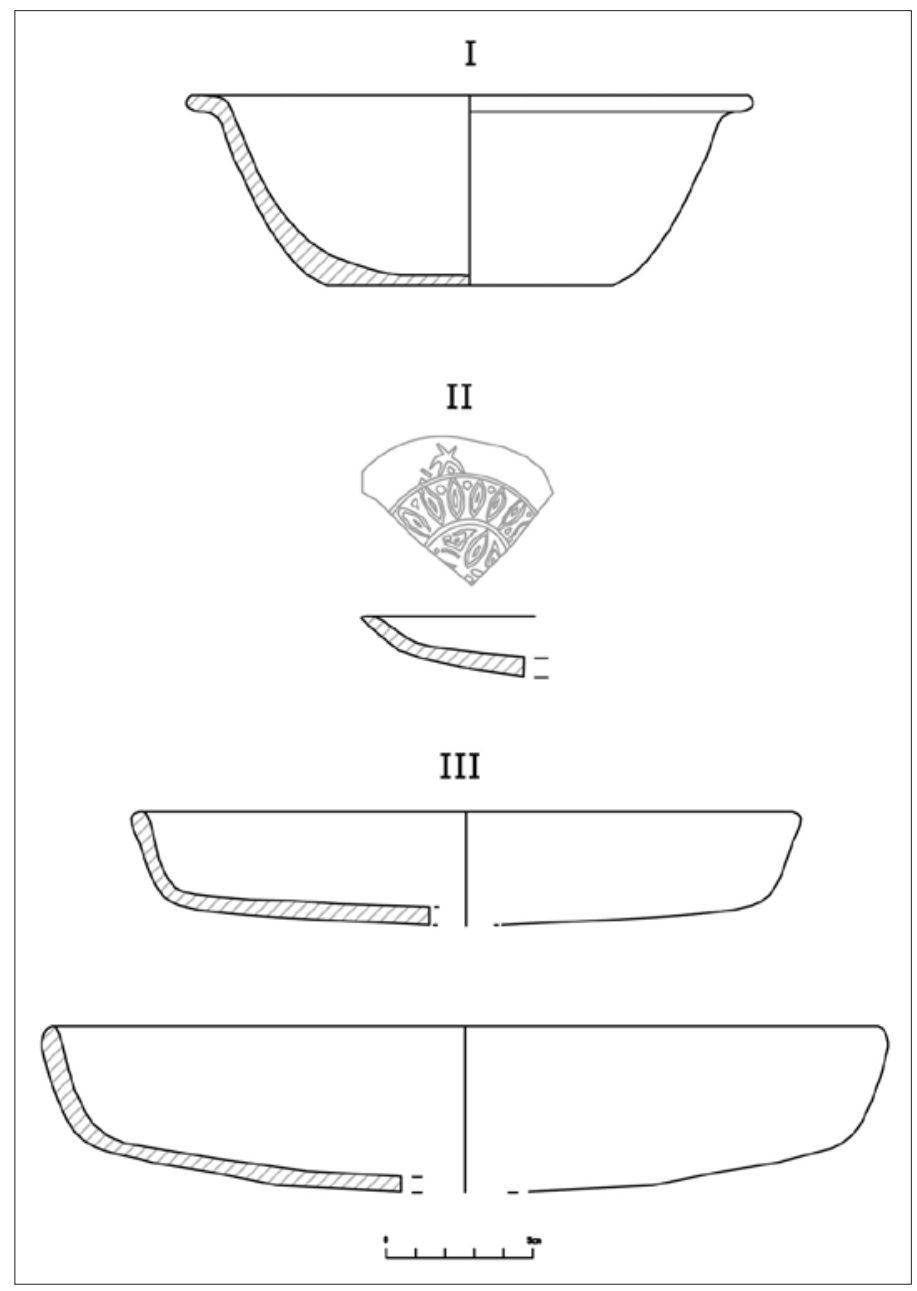

Fig. II. Cerámica vidriada. Ataifores. Tipos I-III. 


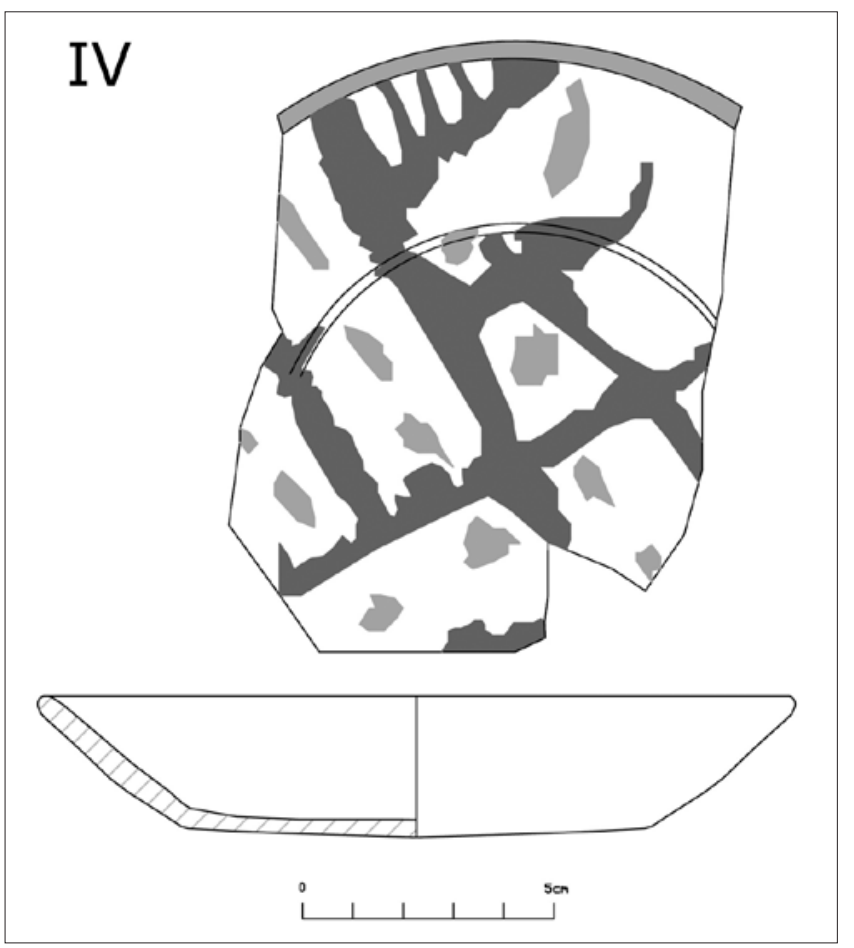

Fig. I2. Cerámica vidriada. Ataifor. Tipo IV.

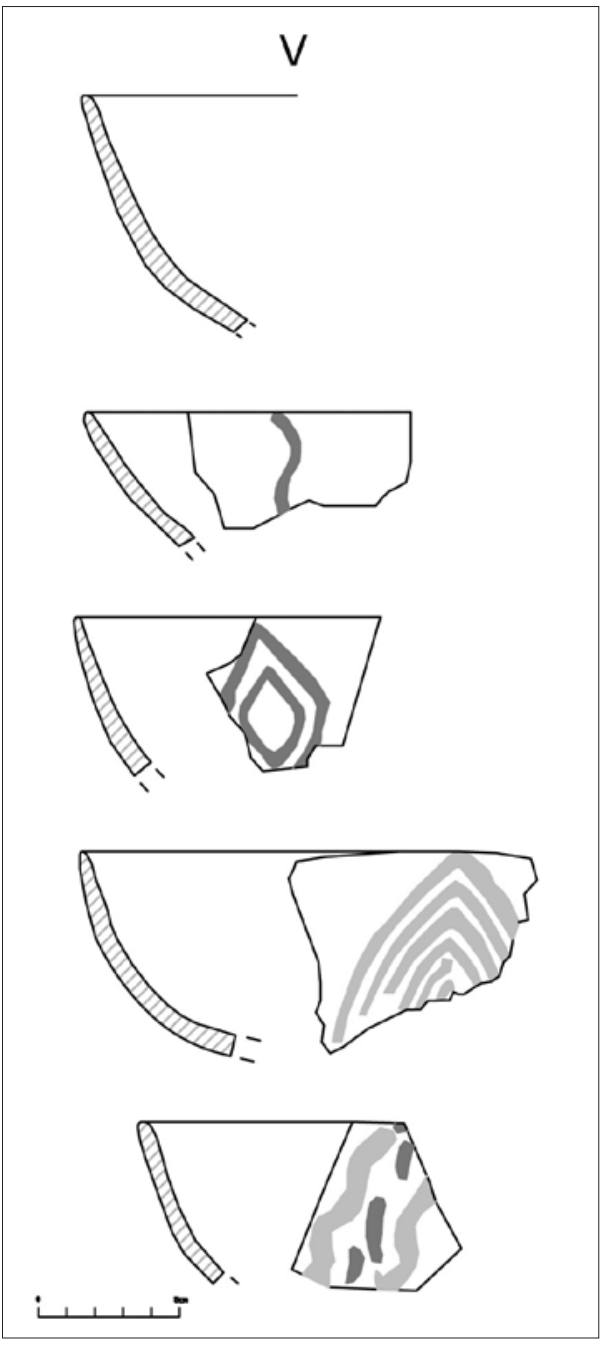

Fig. I3. Cerámica vidriada. Ataifores. Tipo V.
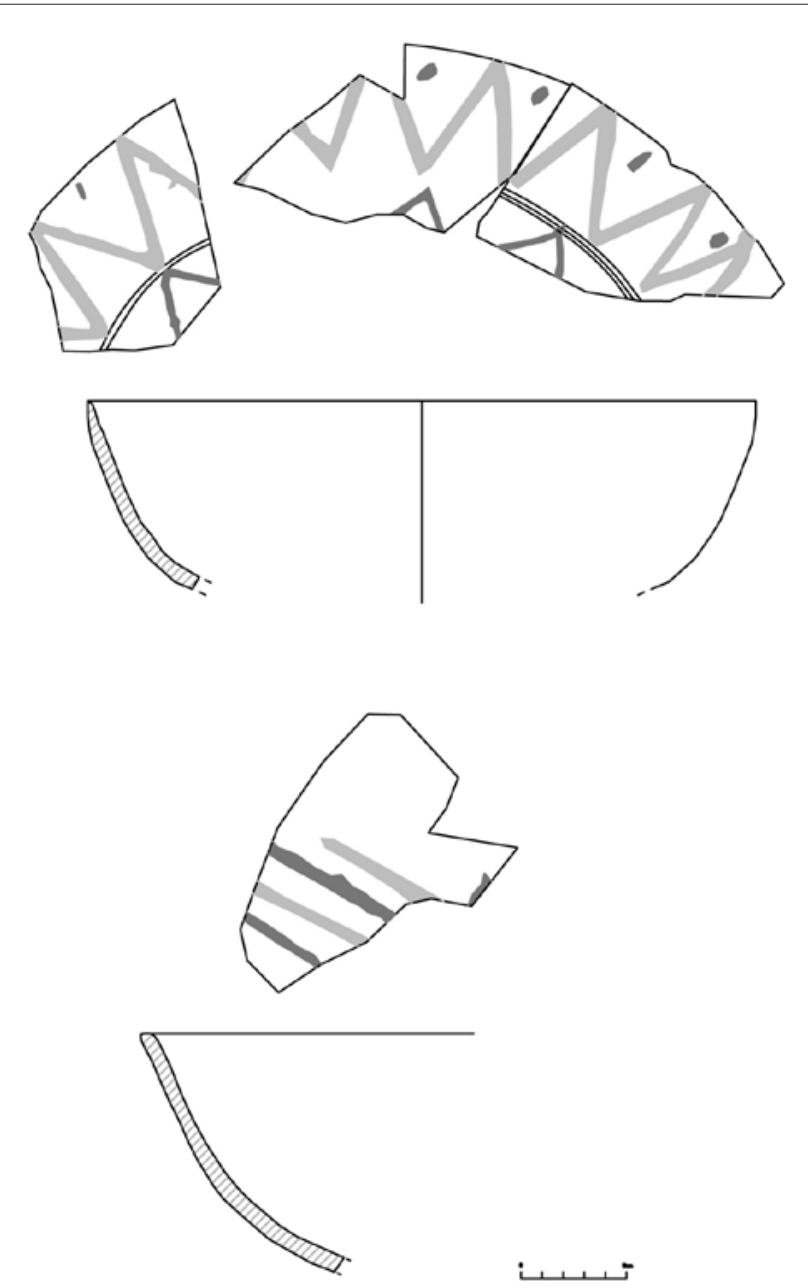

Fig. I4. Cerámica vidriada. Ataifores. Tipo V. 


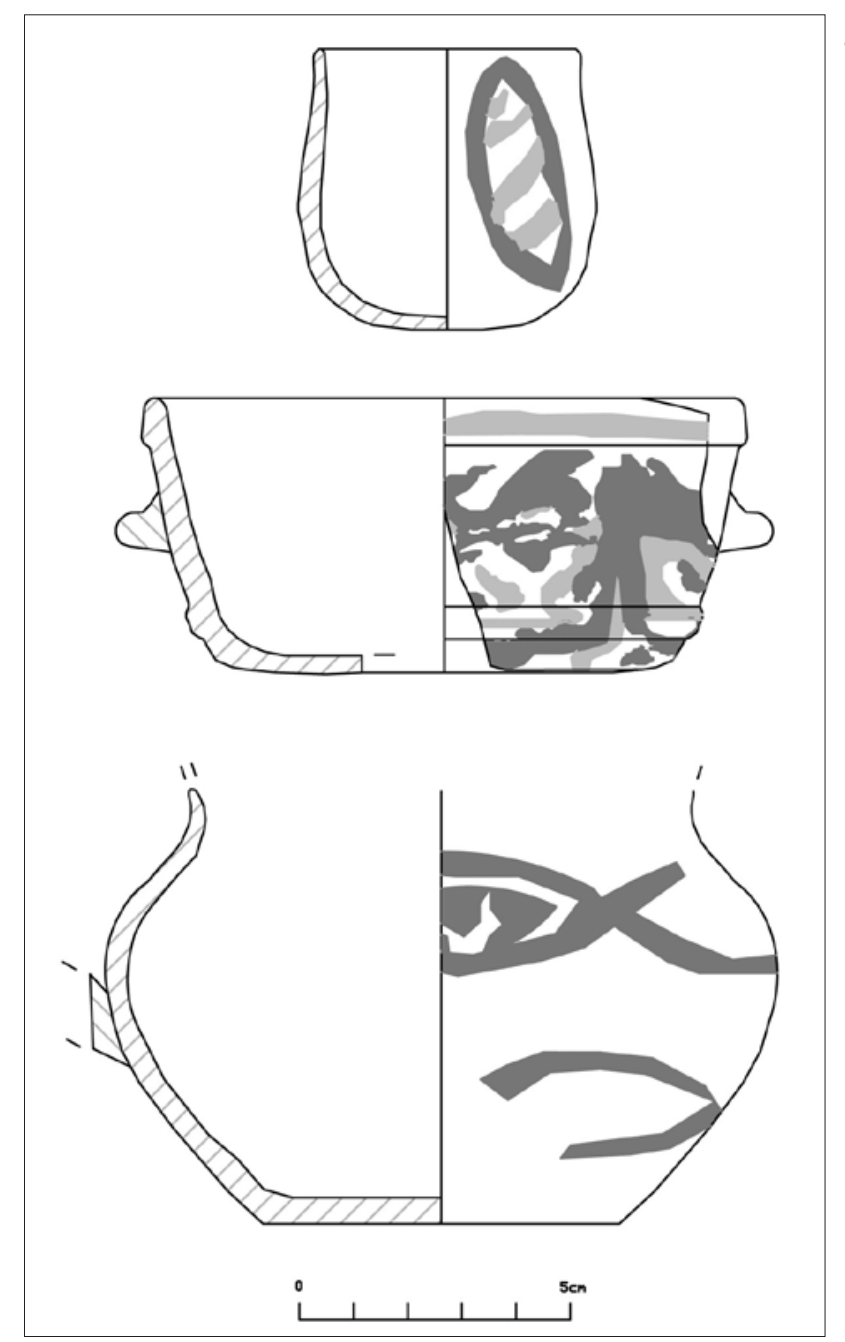

Fig. I5. Cerámica vidriada. Cuenco, taza y jarrito.

Fig. I6. Cerámica vidriada. Taza.

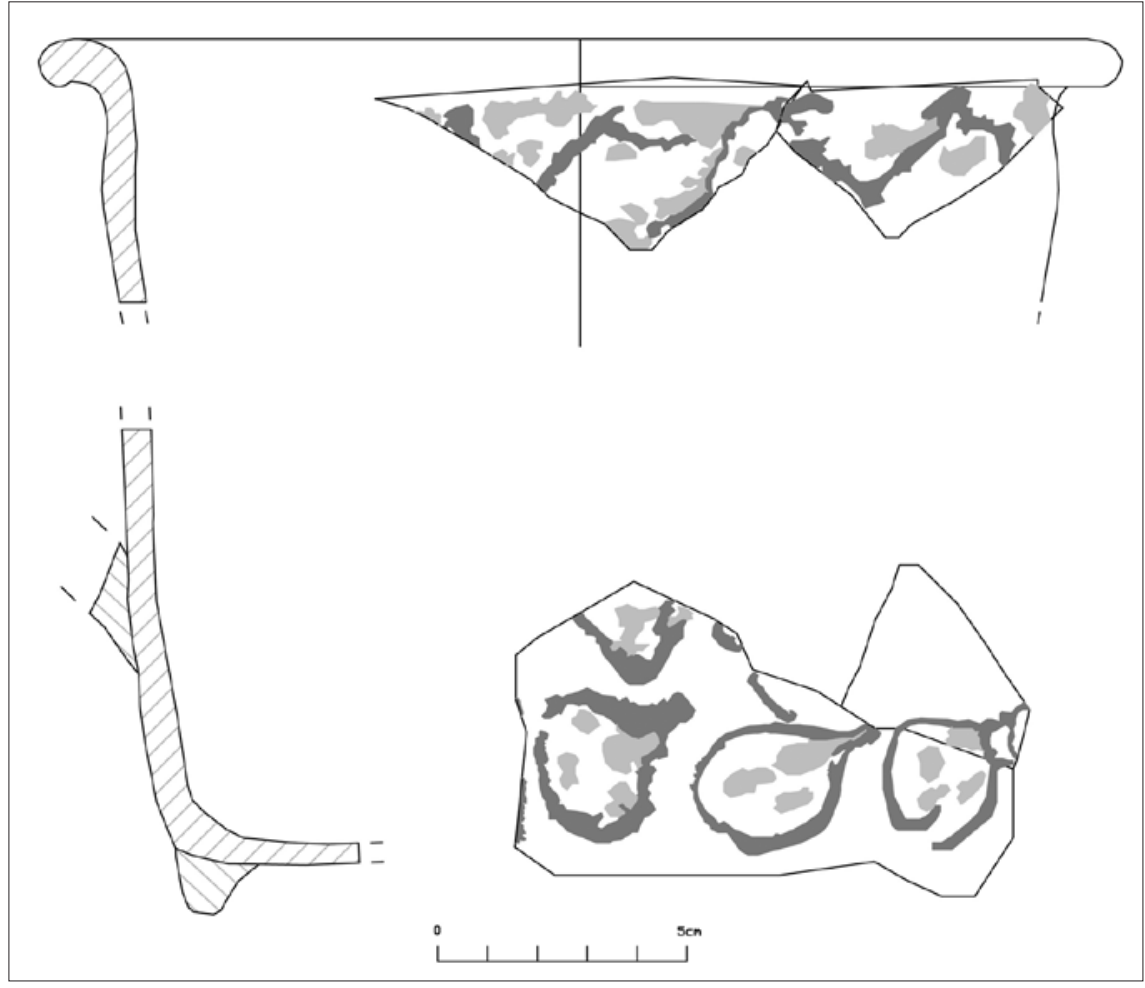




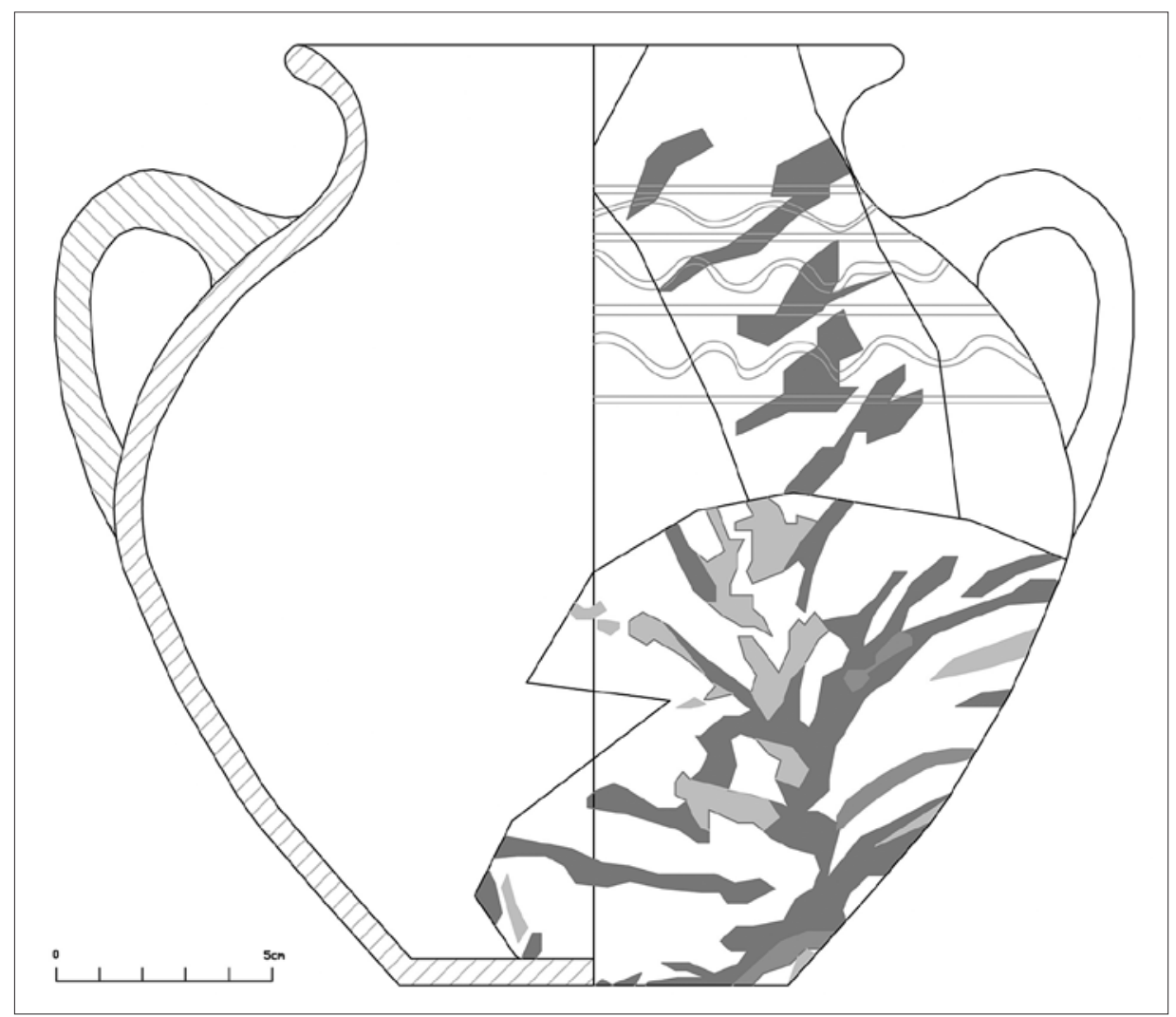

Fig. I7. Cerámica vidriada. Orza.

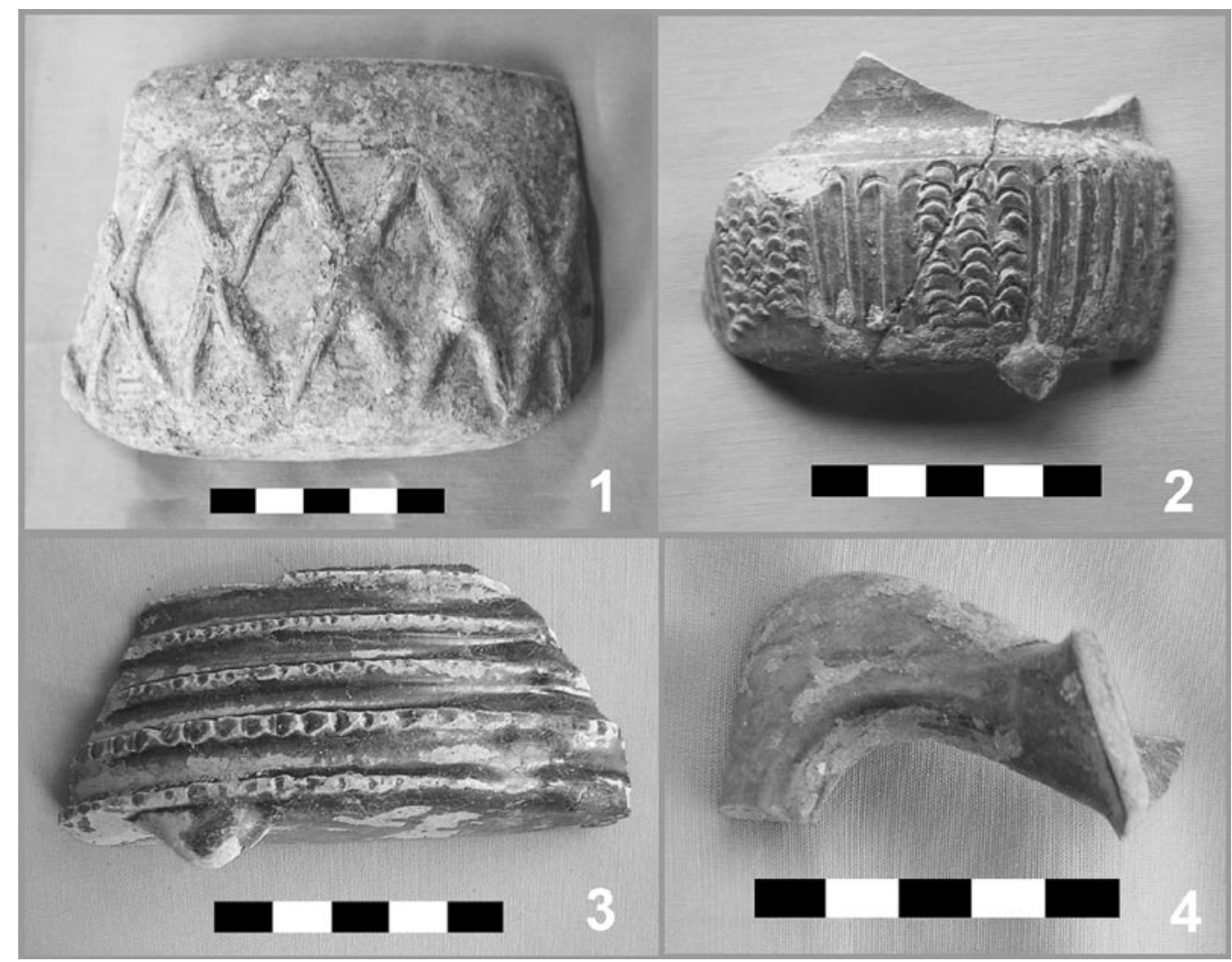

Lám. I. Ejemplos de vidriados emirales cordobeses: 1:1 - 1:3. Cuenco y jarros procedentes de Ma . Auxiliadora. 1:4. Asa de un jarro localizado en el Patio de Mujeres del Alcázar. 

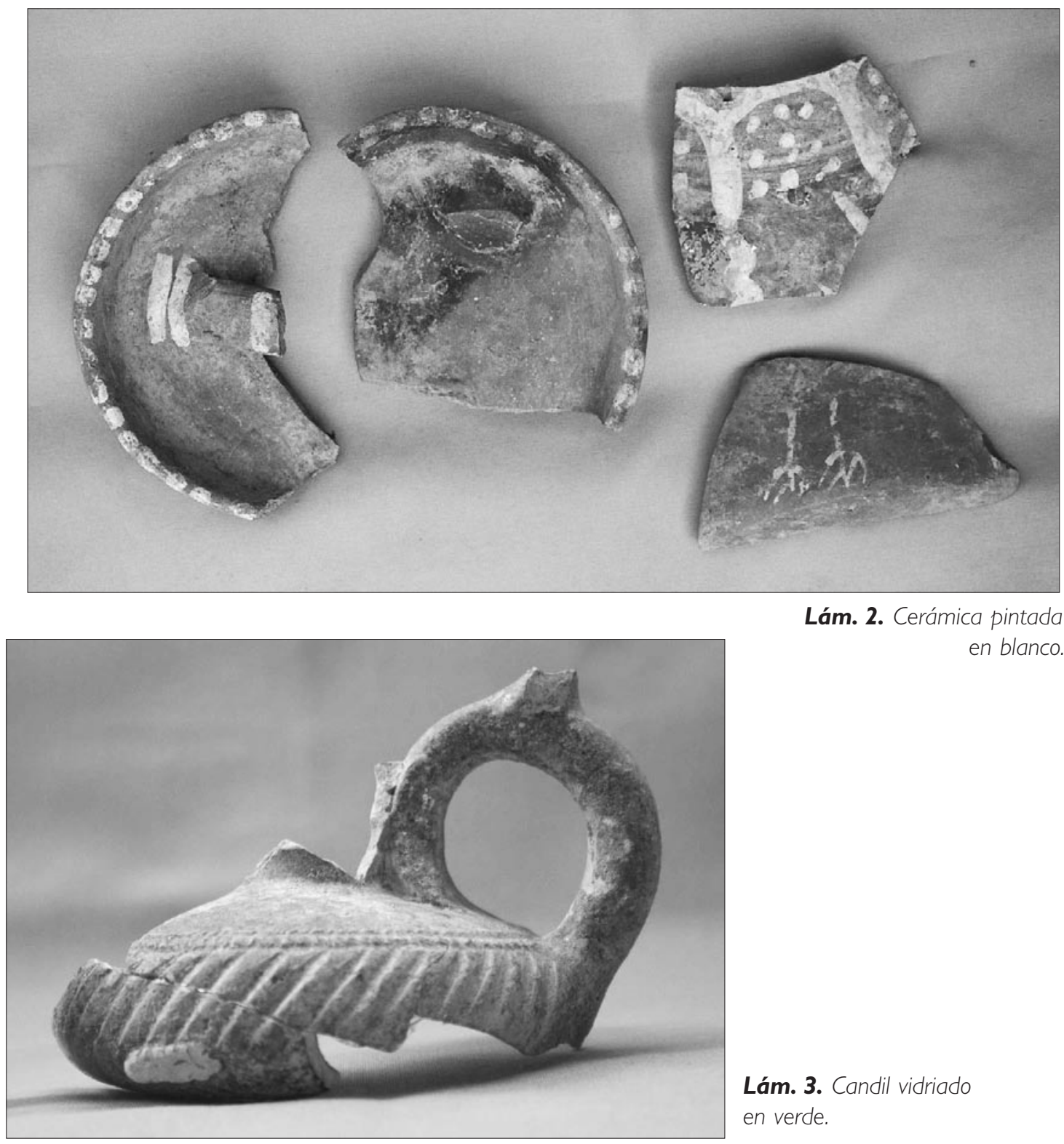

Lám. 2. Cerámica pintada en blanco.

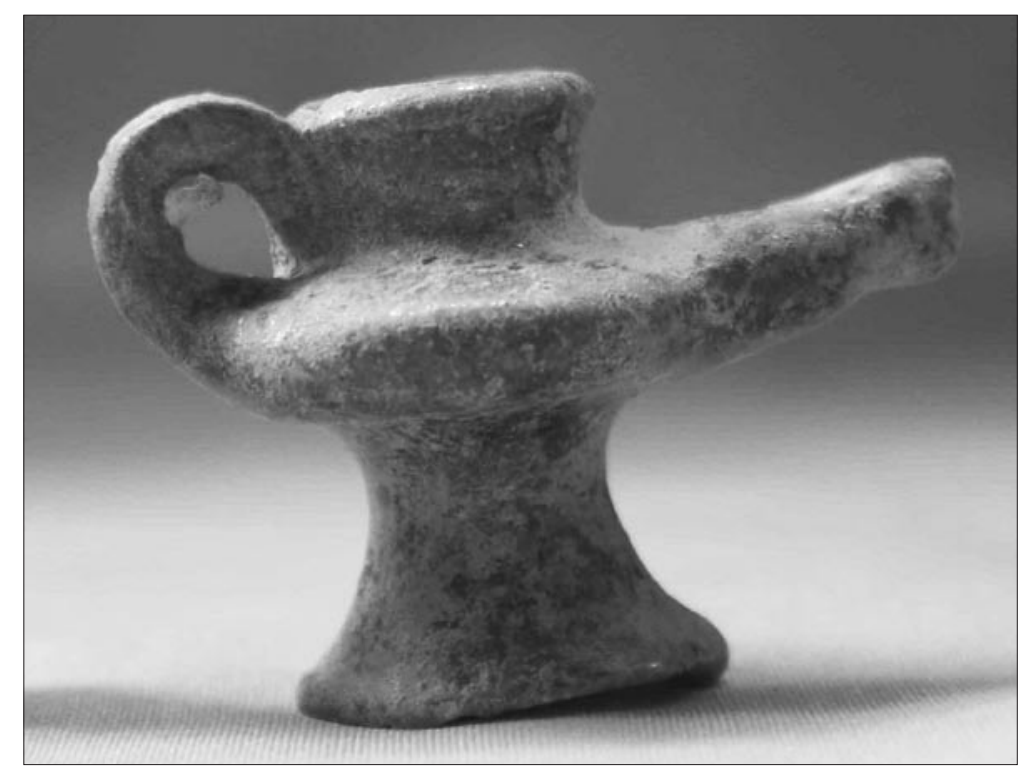

Lám. 3. Candil vidriado en verde.

Lám. 4. Candil en miniatura vidriado en verde. 


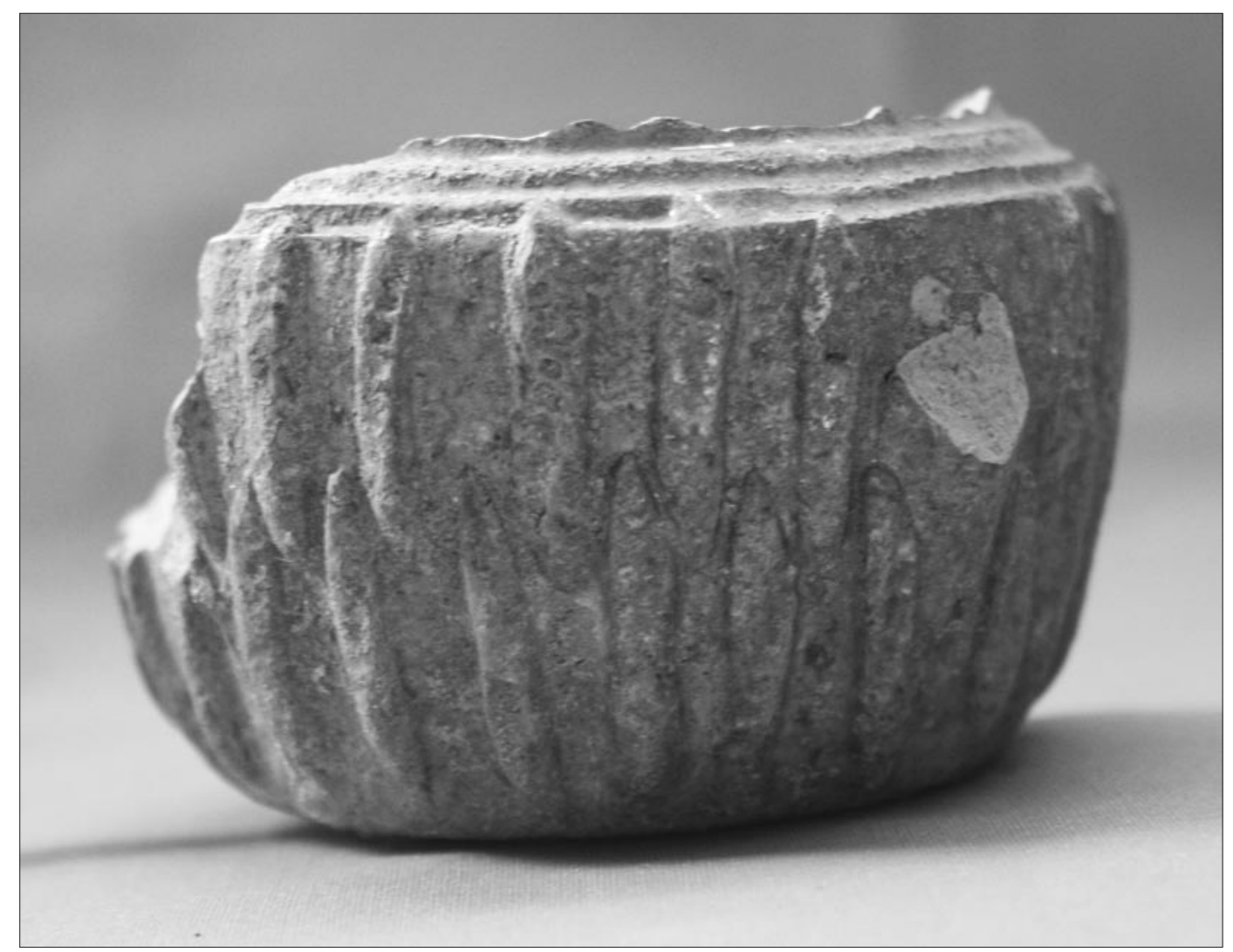

Lám. 5. Jarrito vidriado en melado.

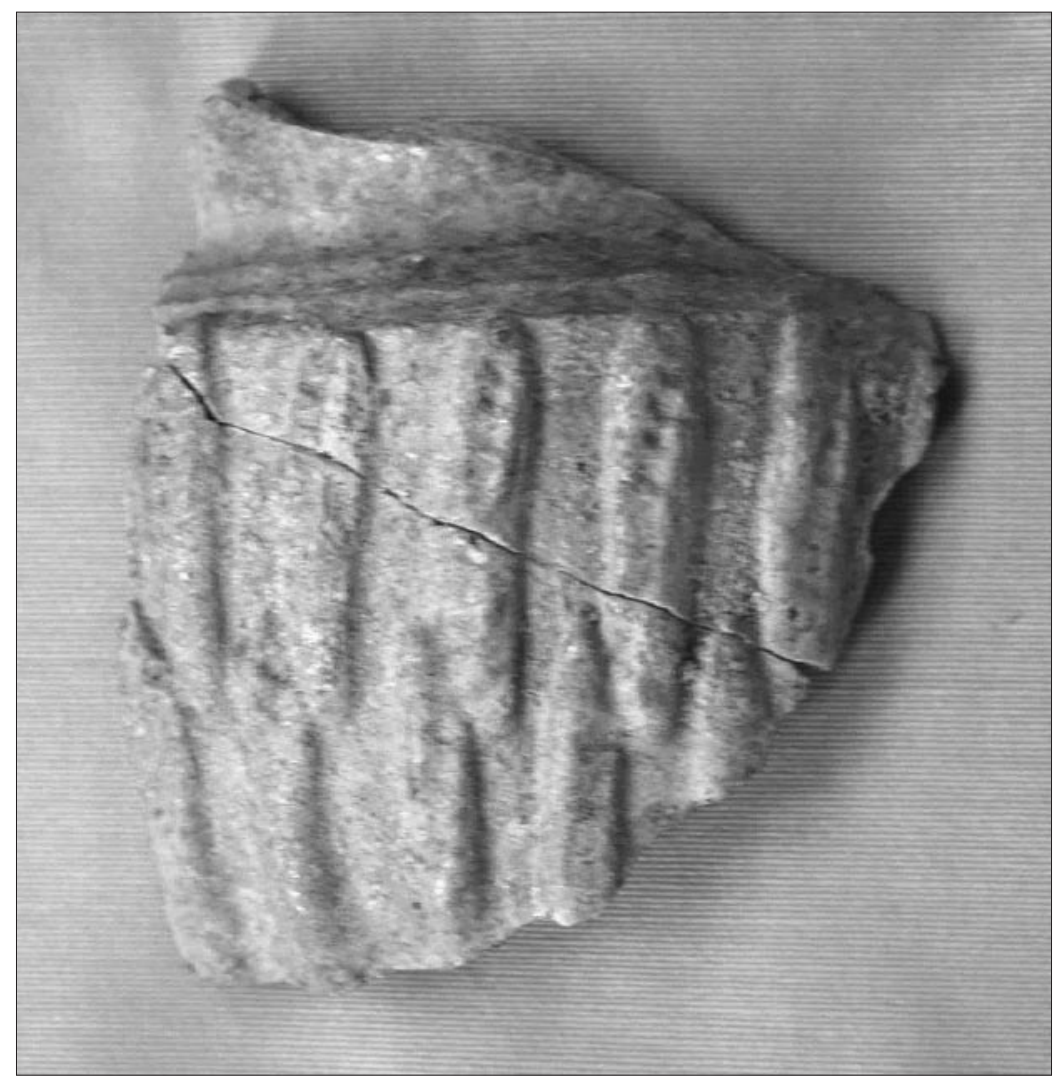

Lám. 6. Detalle de jarrito vidriado melado con aplicación de nervios verticales. 

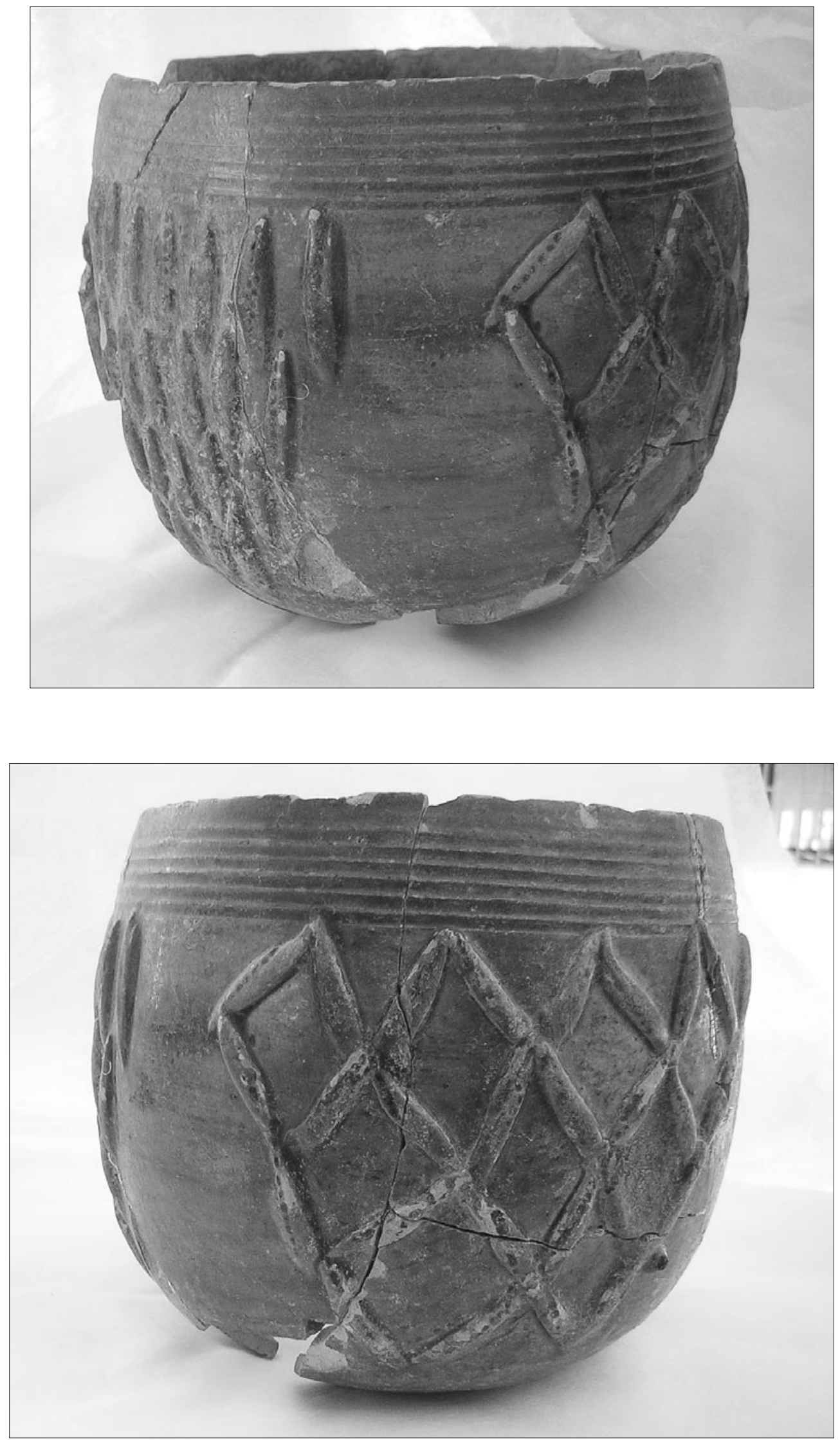

Lám. 7 y 8. Cuenco vidriado bícromo exterior melado/ achocolatado e interior verde, con aplicación de nervios verticales y romboidales. 


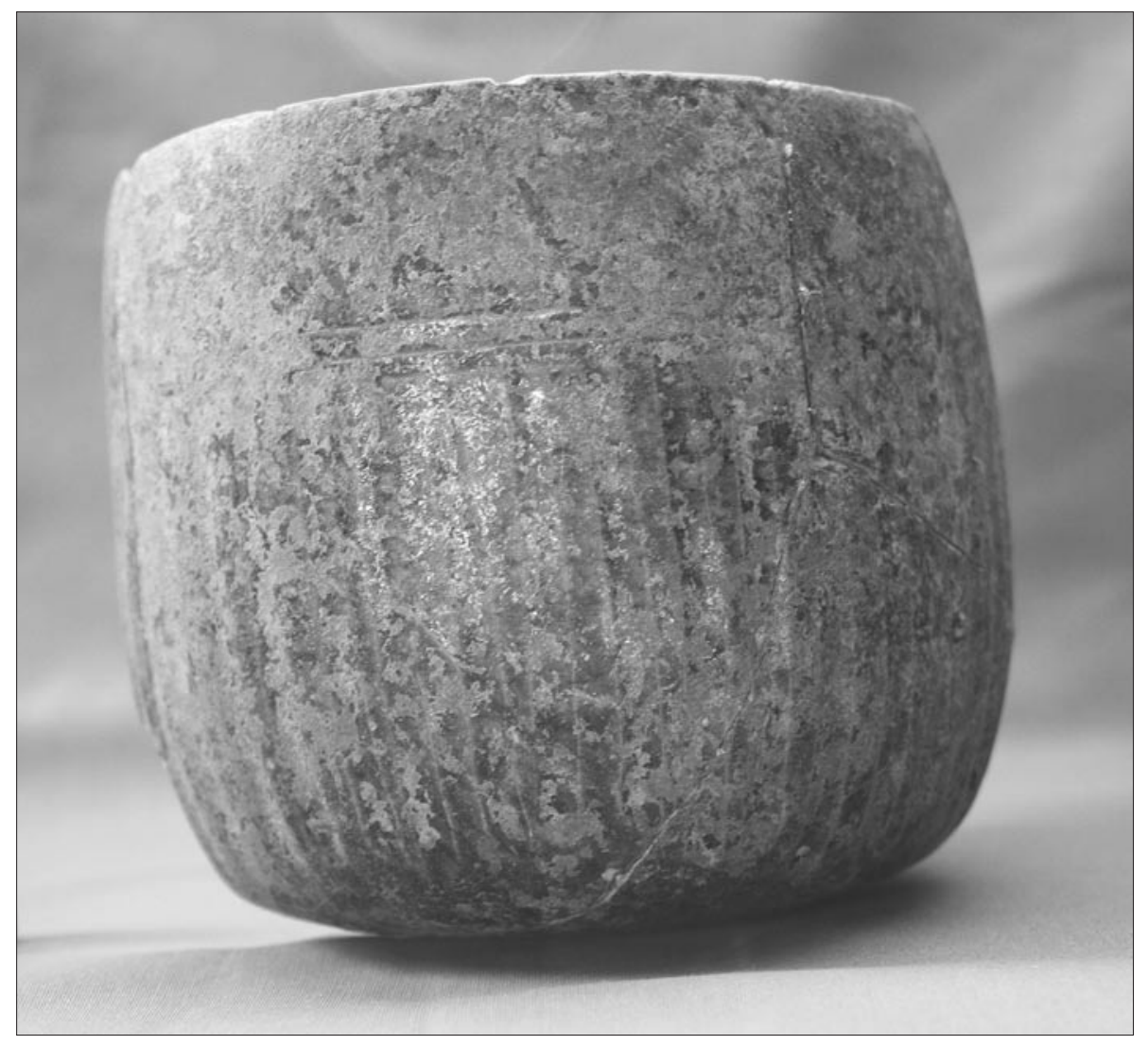

Lám. 9. Cuenco vidriado en melado con costillas.

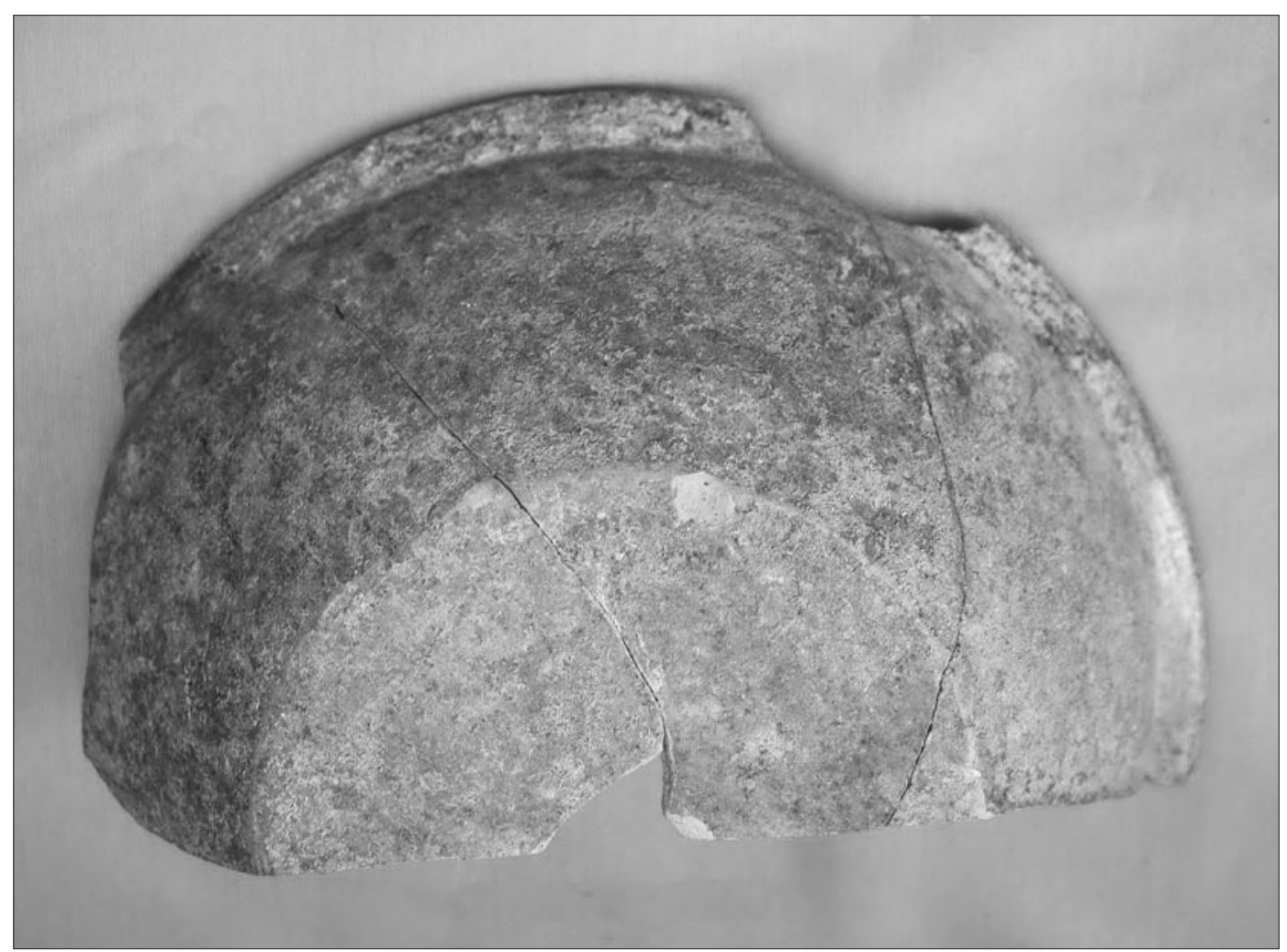

Lám. 10. Ataifor vidriado bícromo exterior melado e interior y borde verde. 


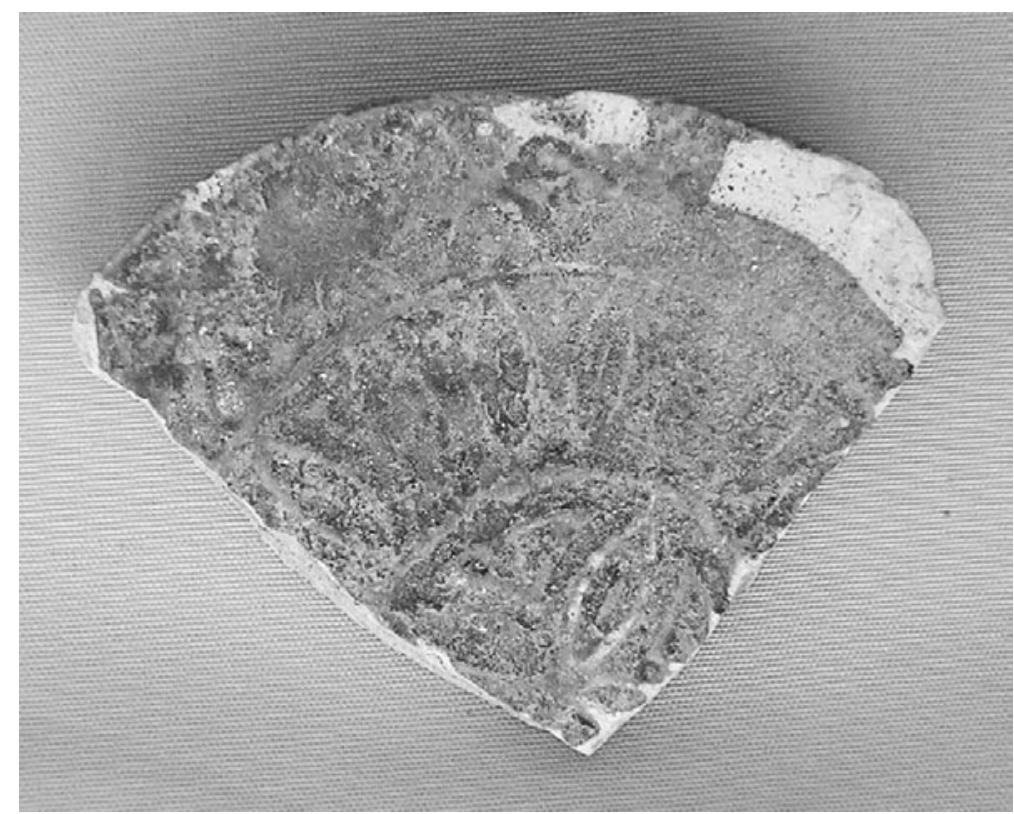

Lám. I I. Ataifor vidriado en melado con impresión.

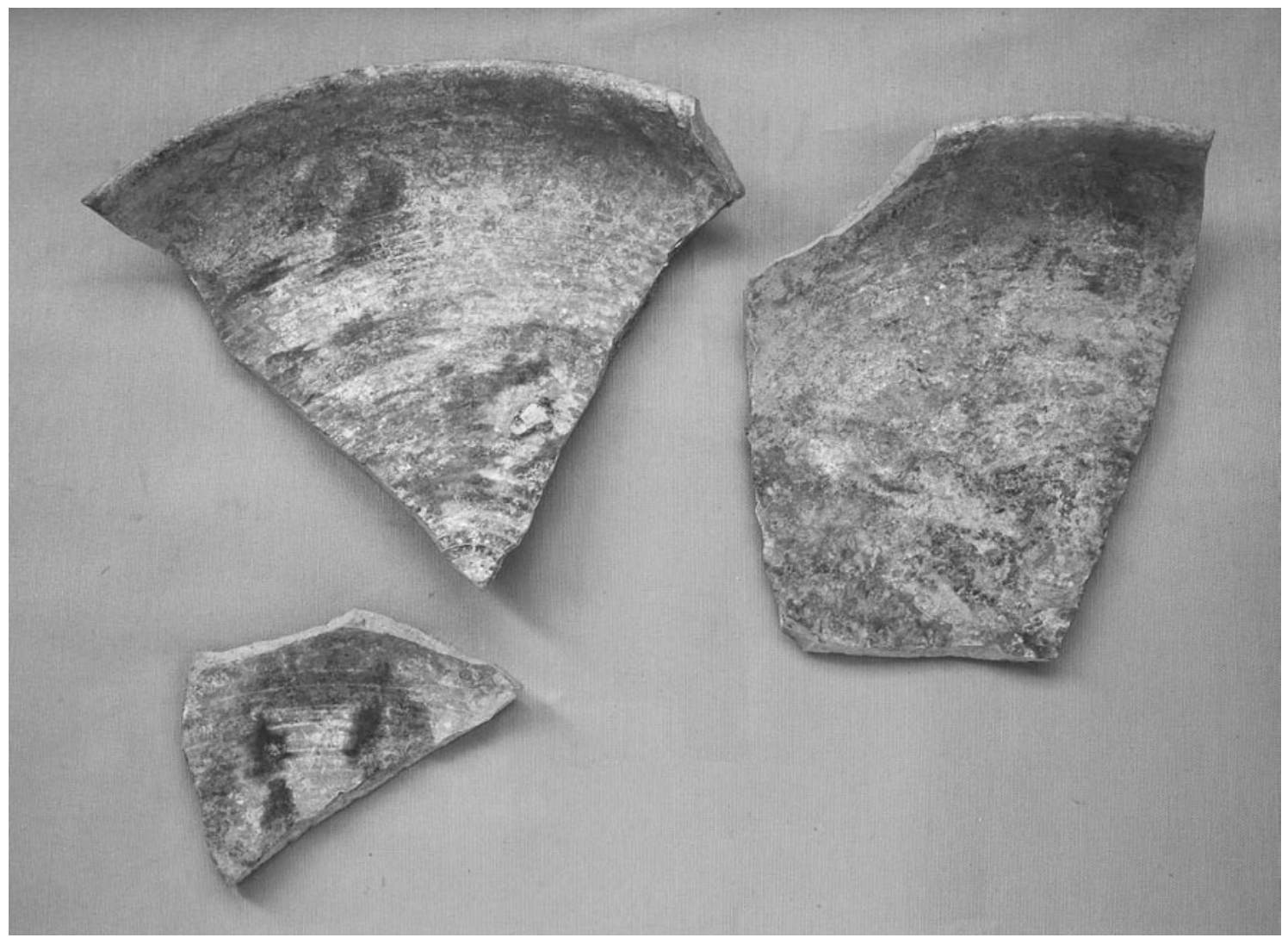

Lám. I2. Ataifor vidriado polícromo: trazos verdes y negros sobre fondo verdoso. 


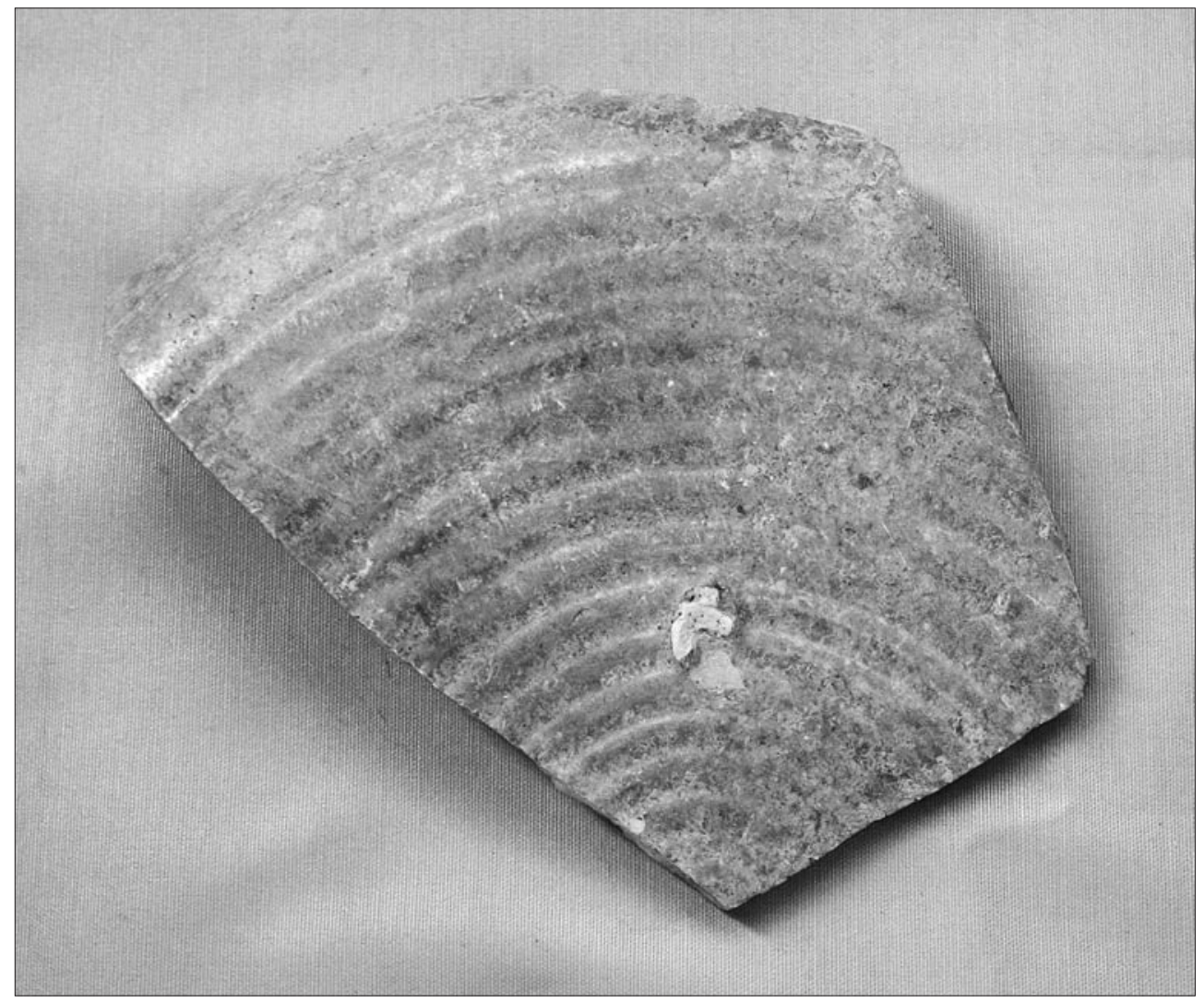

Lám. I3. Detalle de la parte inferior externa de un ataifor vidriado en melado, que conserva la huella del atifle.

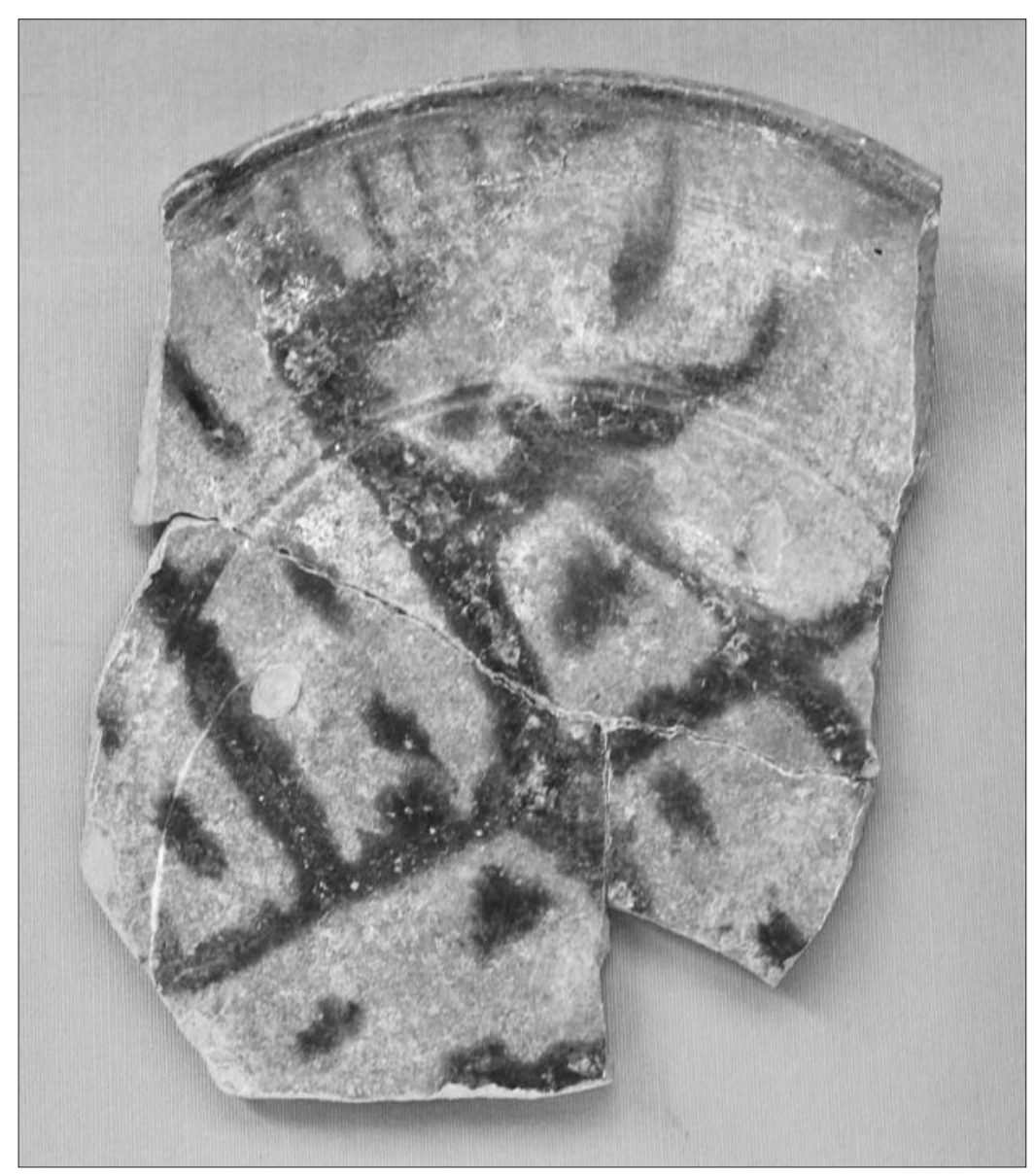

Lám. I4. Ataifor vidriado polícromo: trazos verdes y negros sobre fondo verdoso. 


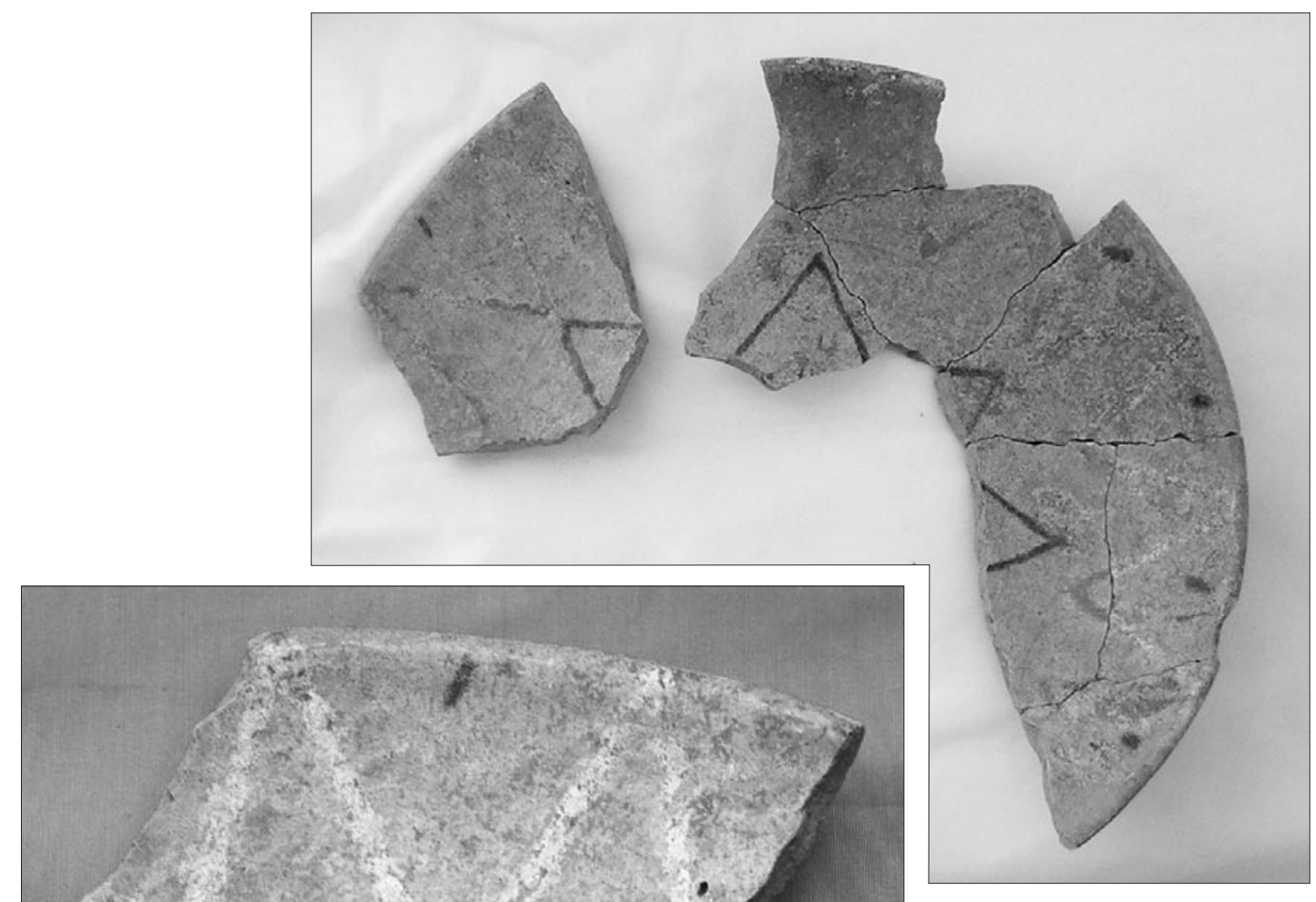

Lám. I5. Ataifor vidriado polícromo: motivos de dientes de sierra verdes y negros con fondo blanco.

Lám. I6. Detalle de ataifor: motivos de dientes de sierra verdes y negros con fondo blanco.

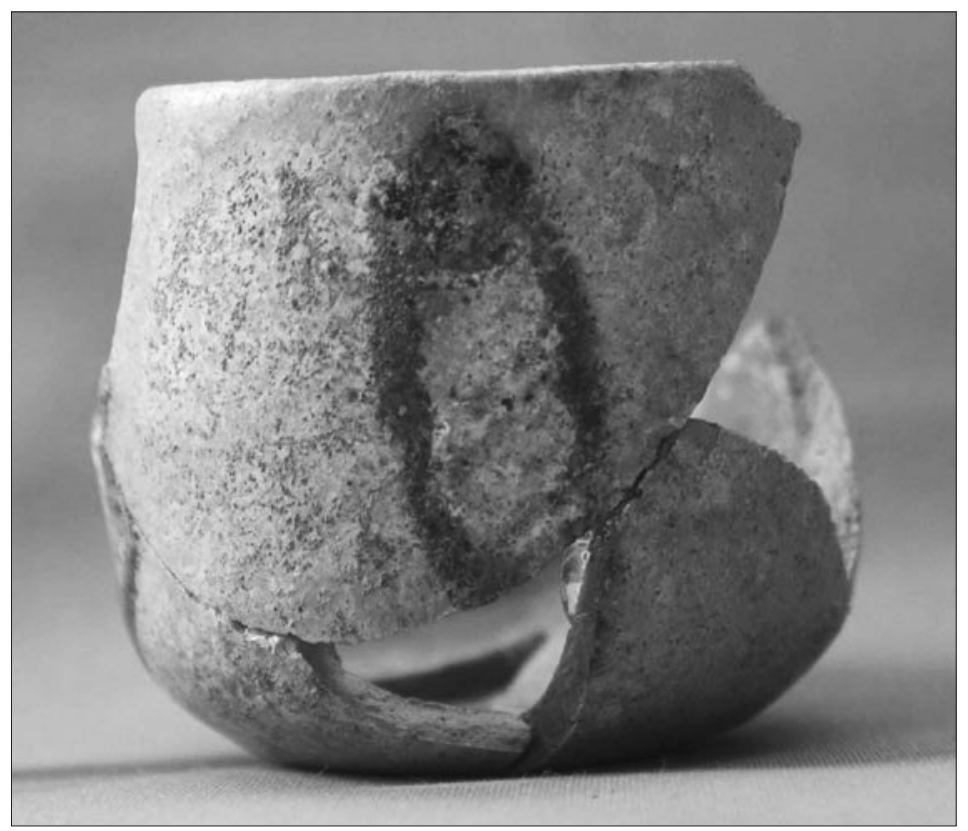

Lám. I7. Pequeño cuenco con vidriado polícromo: trazos verdes azulados y negros con fondo blanco. 


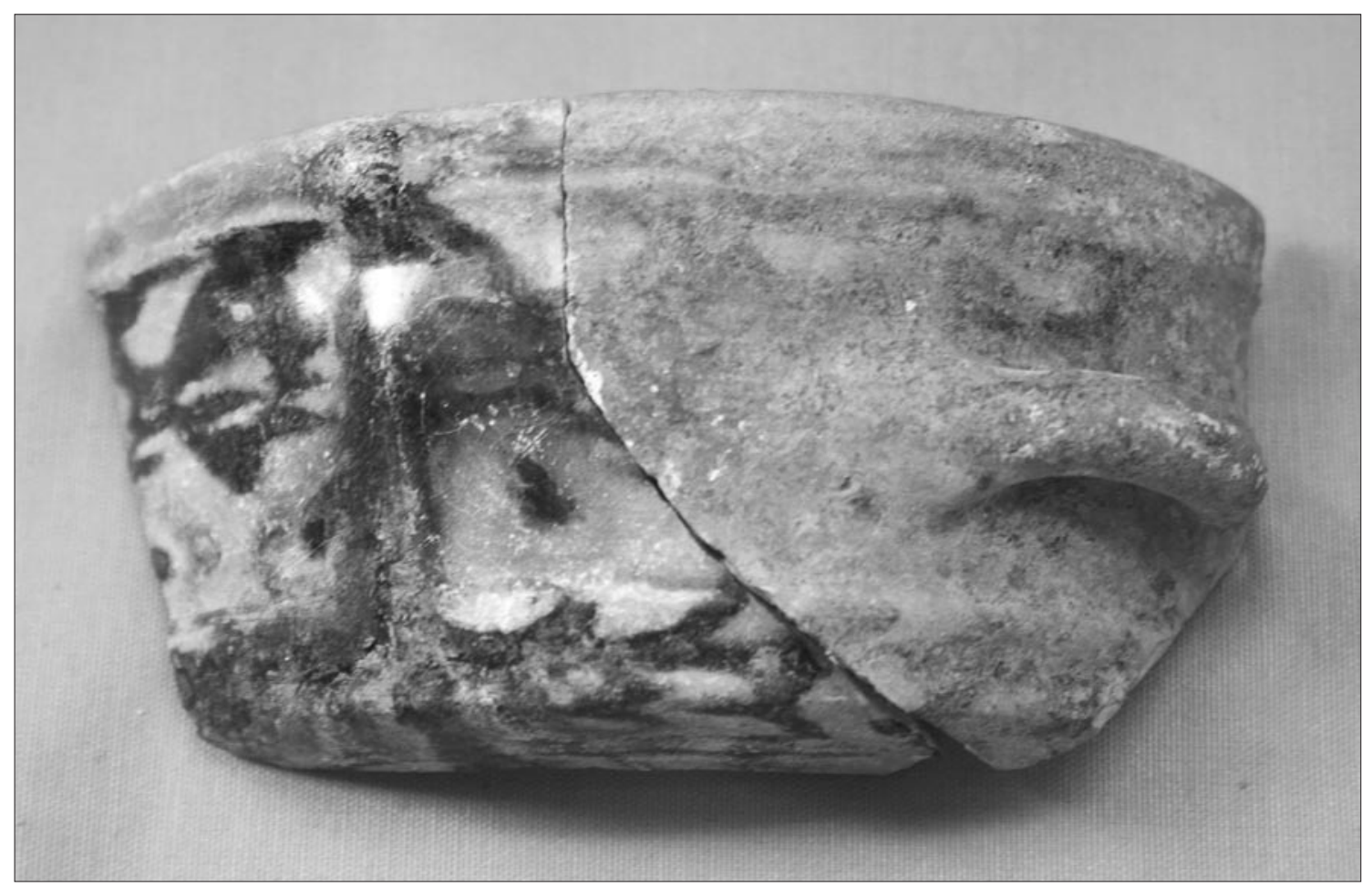

Lám. I 8. Taza vidriada polícroma: trazos verdes y negros sobre fondo melado claro.

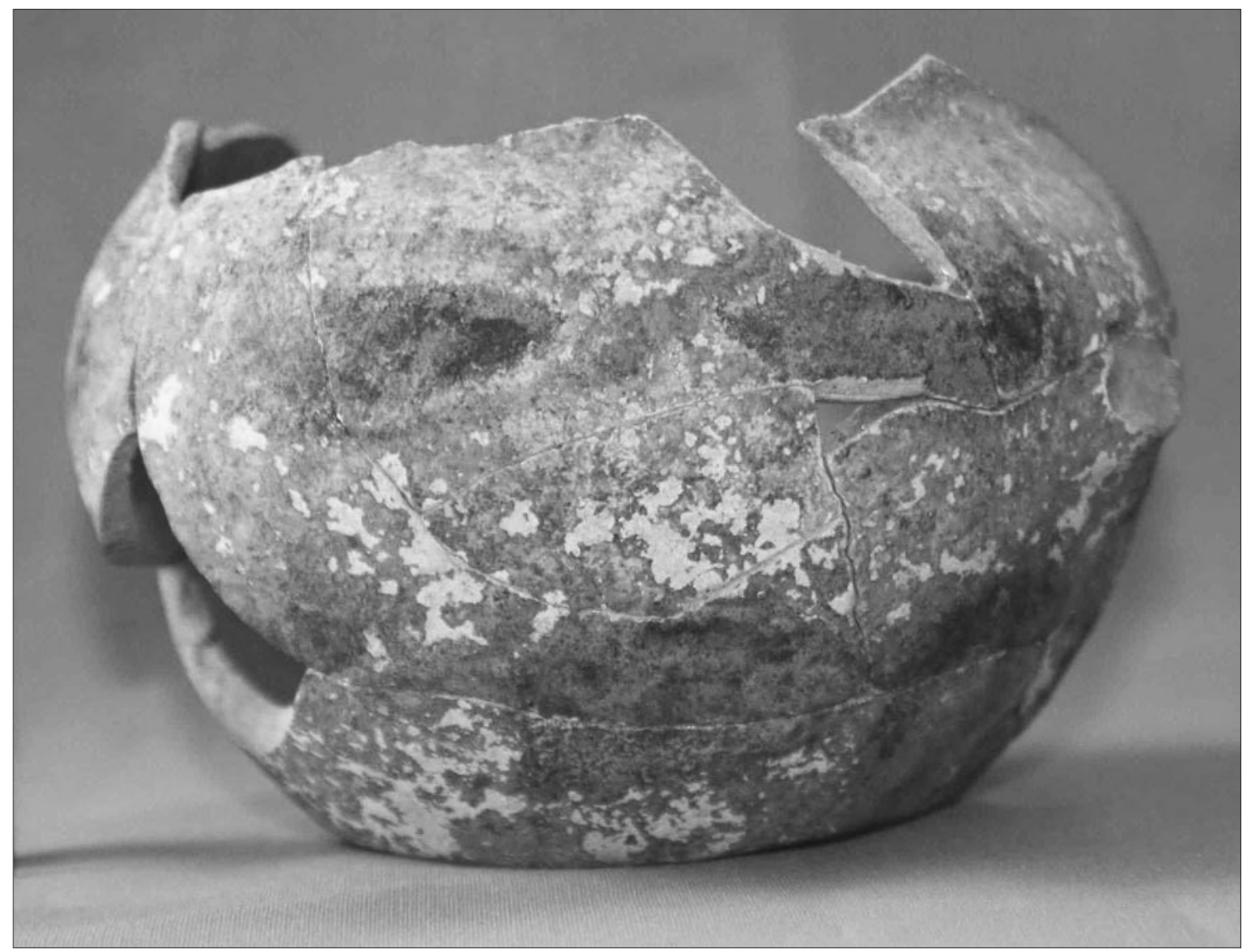

Lám. 19. Jarro vidriado polícromo: trazos verdes y negros sobre fondo blanco. 

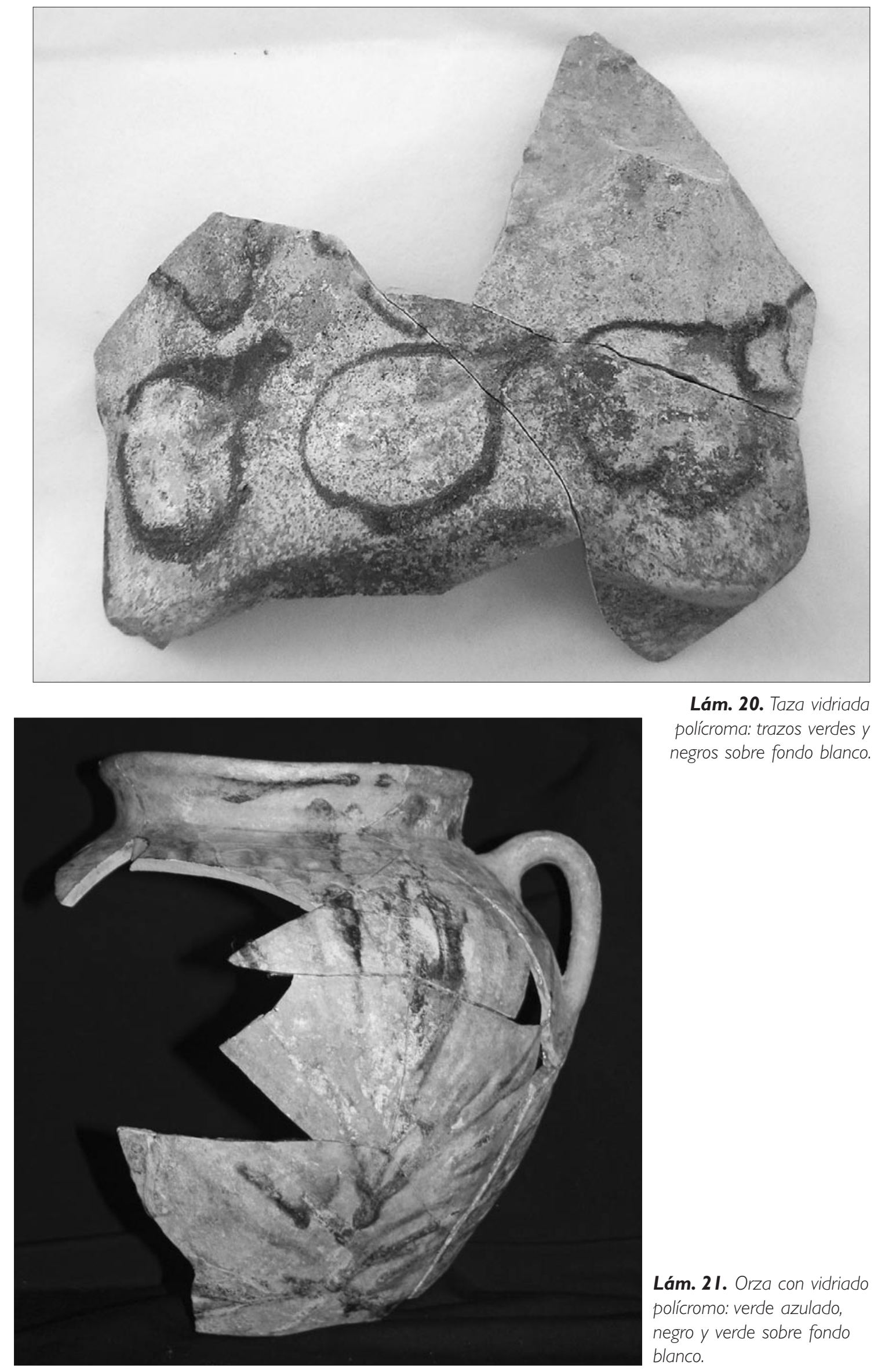

Lám. 20. Taza vidriada polícroma: trazos verdes y negros sobre fondo blanco.

Lám. 2 I. Orza con vidriado polícromo: verde azulado, negro y verde sobre fondo blanco. 


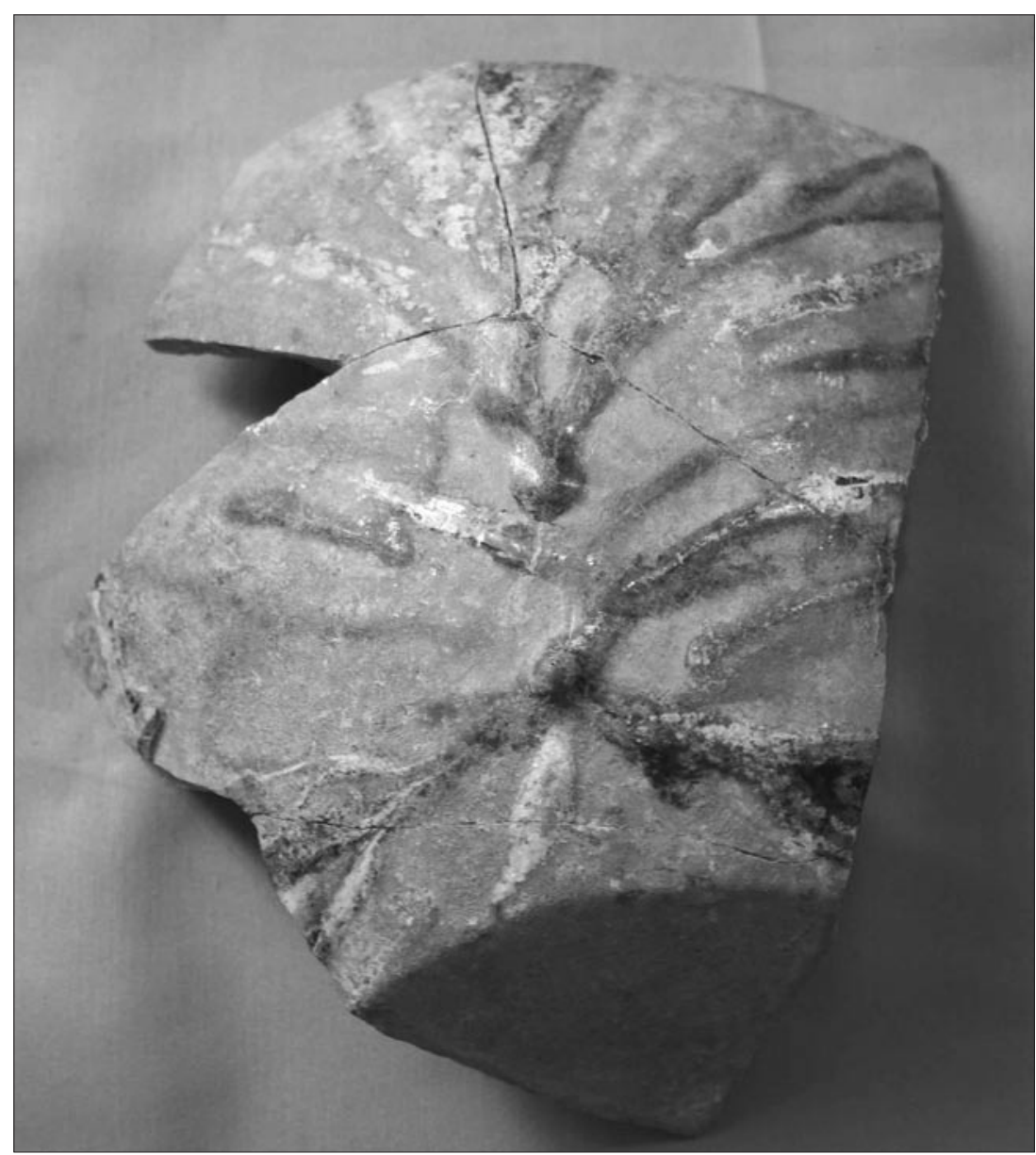

Lám. 22. Detalle de la orza vidriada polícroma a ráfagas: trazos verdes azulados, negros y melados sobre fondo blanco. 